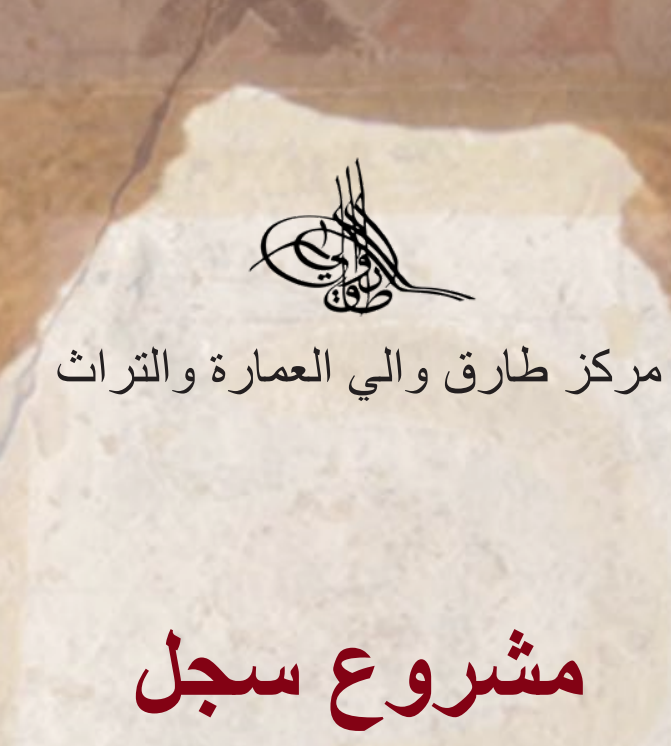

الأديرة القبطية .. شواهد من تاريخ مصر ifitis

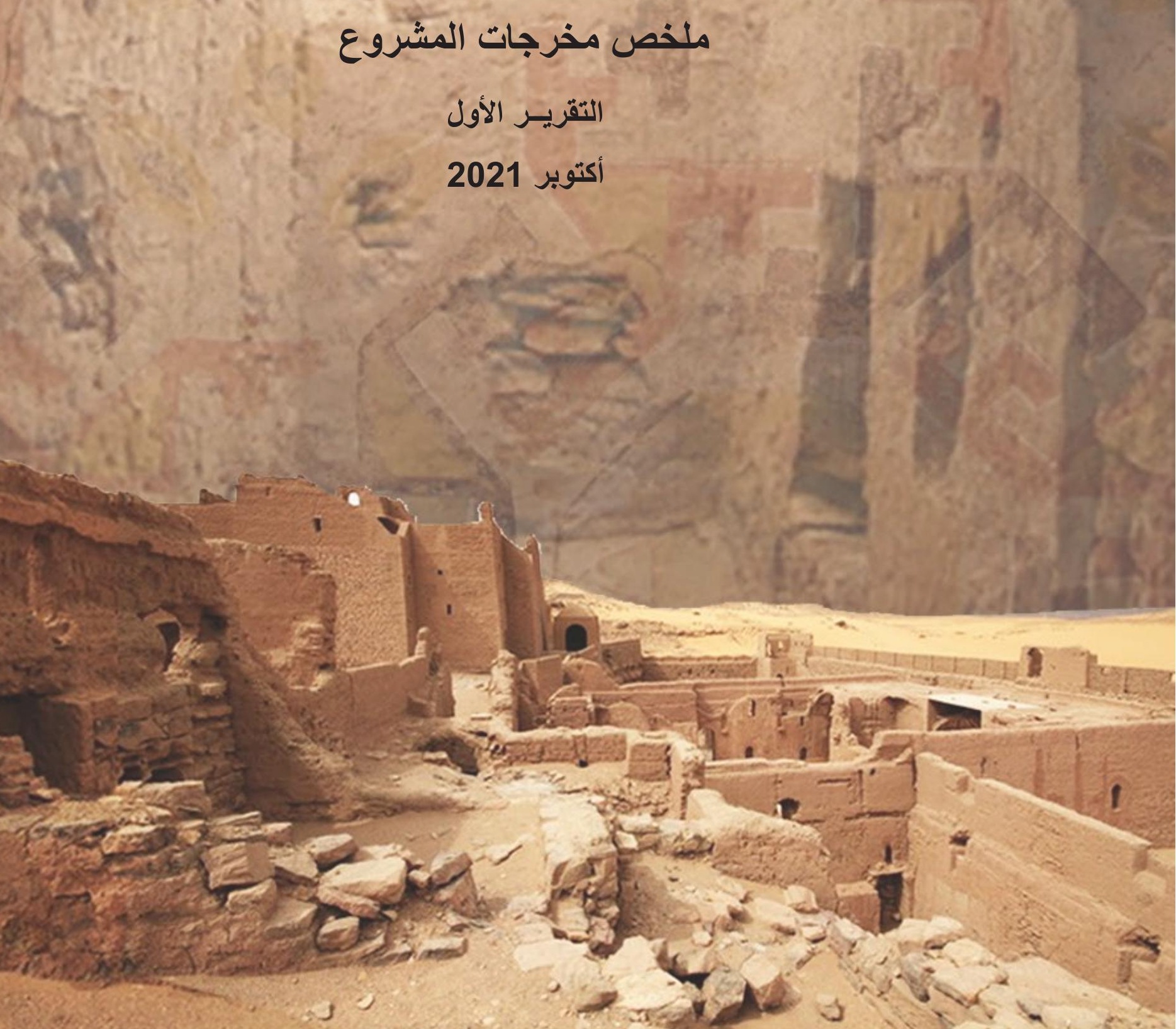




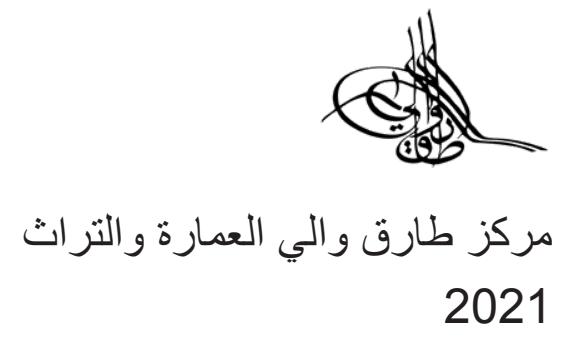

مشروع سجل الأديرة القبطية .. شواعل ستد من تاريخ مصر

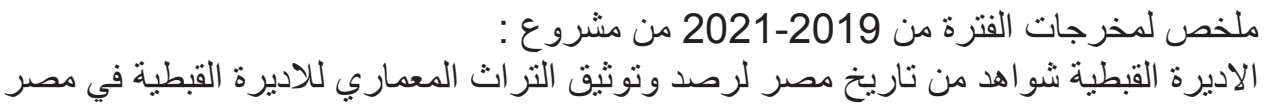

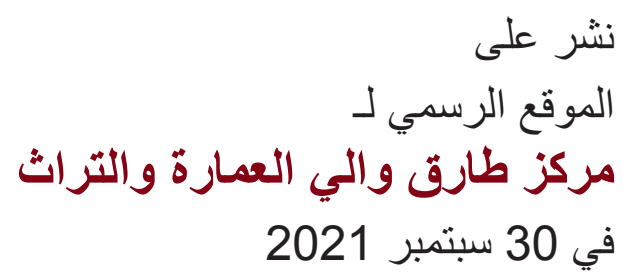
رابط التعريف الرقمي (DOI) https://doi.org/10.47288/TWC.CM.001.2021 


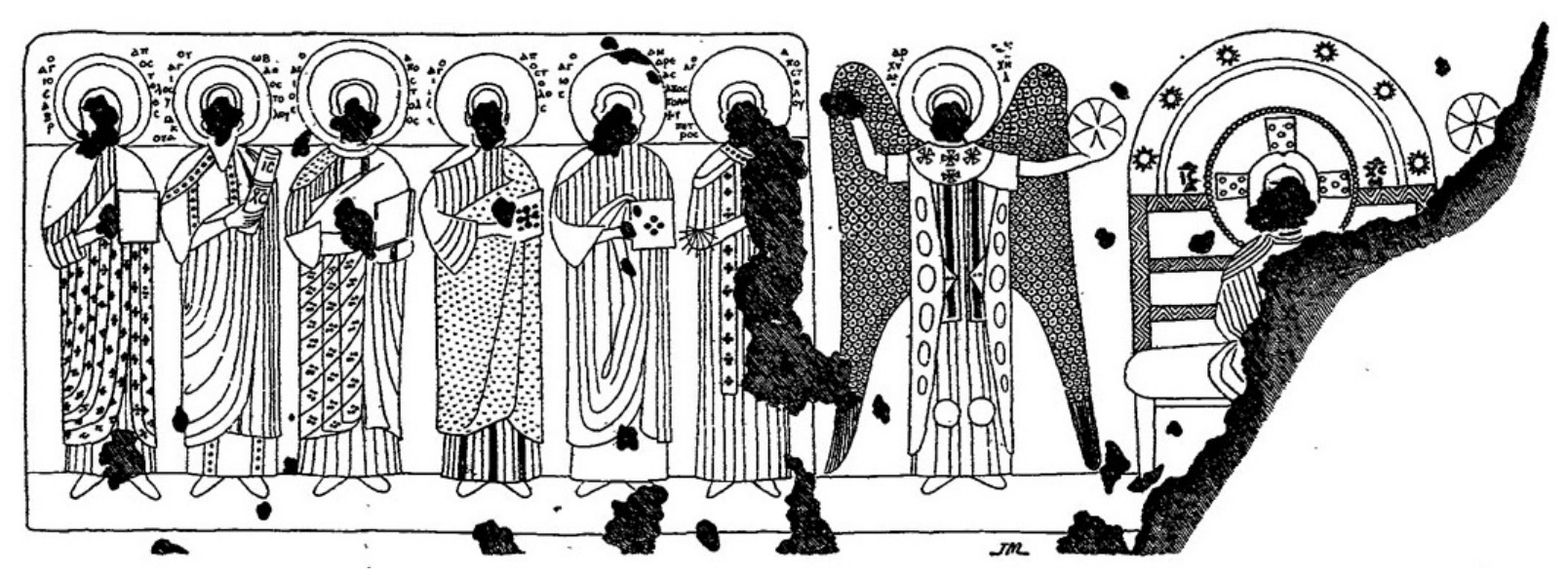

\section{مشروع سجل \\ الأديرة القبطية .. شواهد من تاريخ مصر}

عرفت مصر تتابع مستمر دون انفصال من المصري القديم حتى العصر الحديث ولكن تأخذ حقبات من هذا

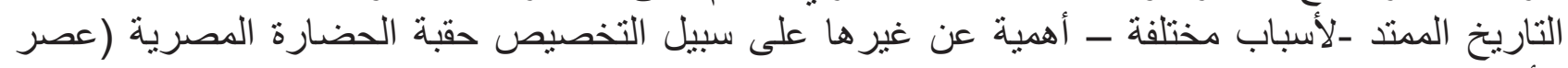

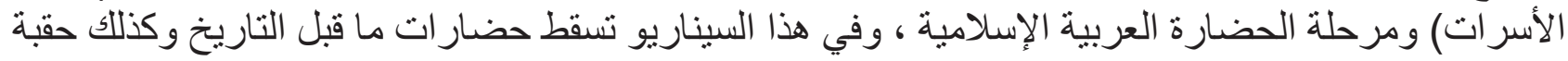

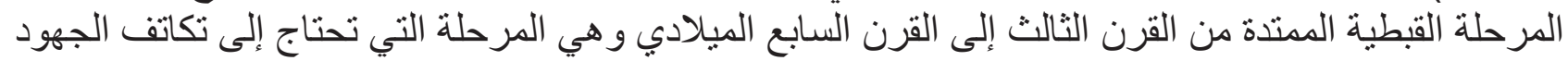

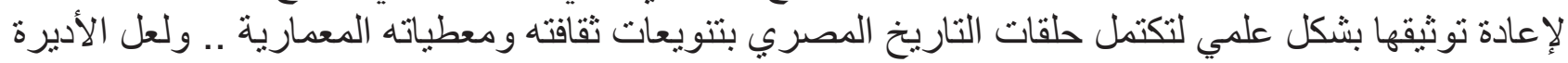

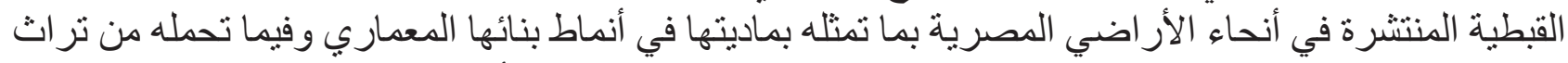

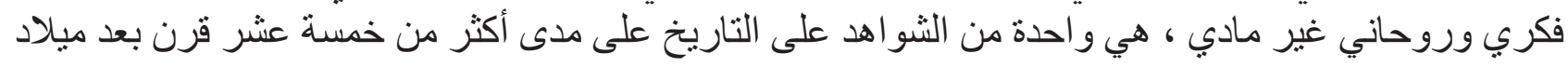

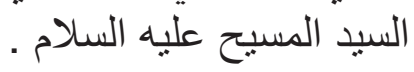

الأديرة المعروفة من كتب الرحالة و المؤرخين و العلماء المتخصصين و التي ماز الت موجودة وتركت أطلال تدل

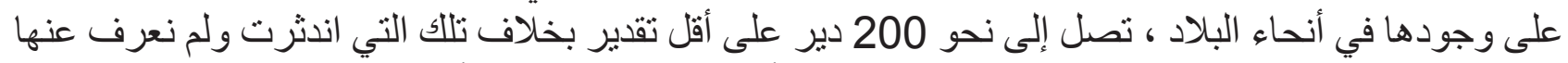

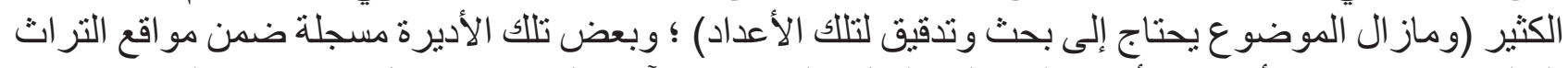

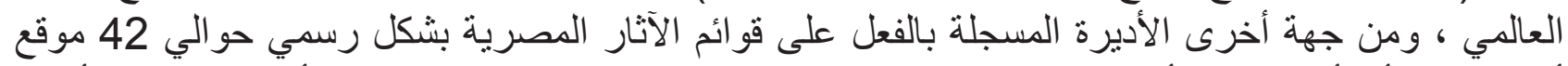

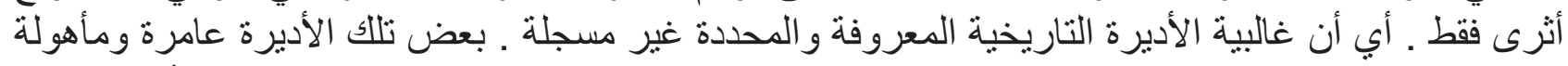

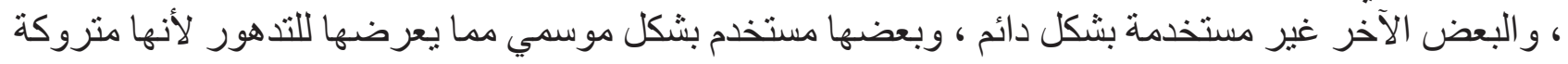
لفعل الزمن وهي مهددة بالاندثار.

الدير .. أحد الثو اهد المعمارية التاريخية على الحضارة القبطية في التاريخ المصري الممتد ، وذكر المؤرخون

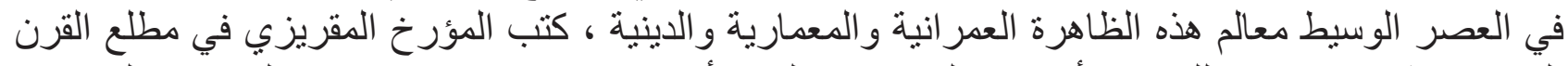

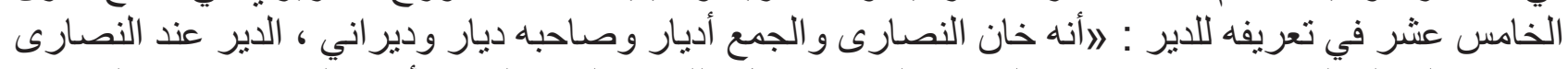

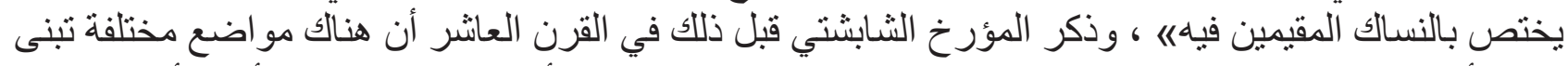

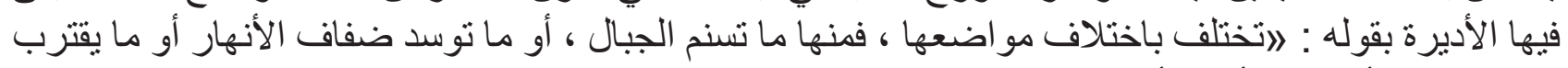

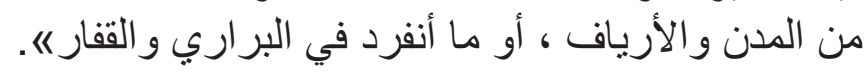


الدير معمارياً يتشكل ويضم بداخله مجموعة من الأبنية تشمل الكنائس والقالالي والحصن أو الحصون والمائدة

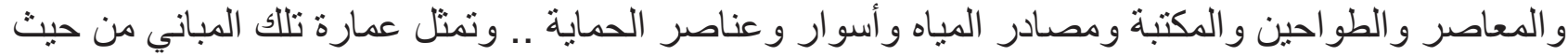
مواد وتقنيات البناء و الفكر التصميمي للمرحلة التاريخية لتأسيسها ومر احل تطور ها ، و والبيئة المحلية لموقعها

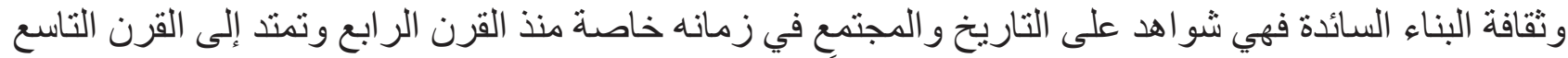

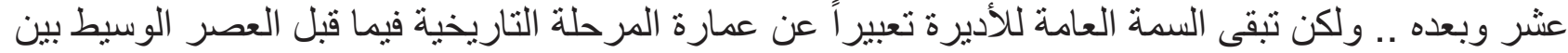

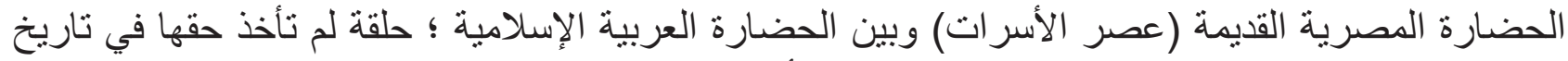

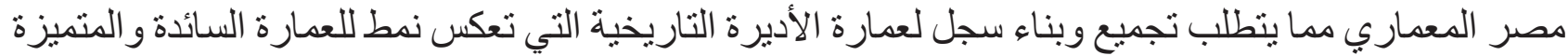

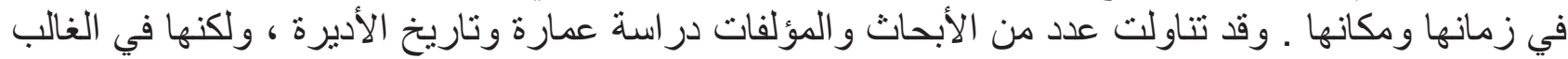

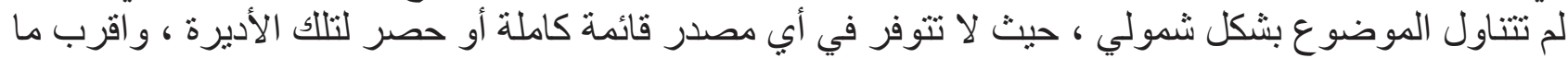

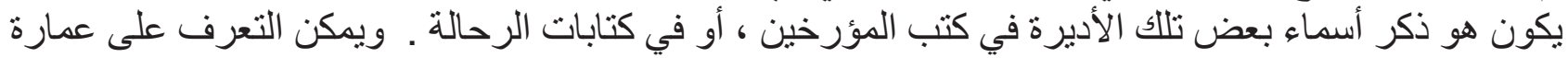

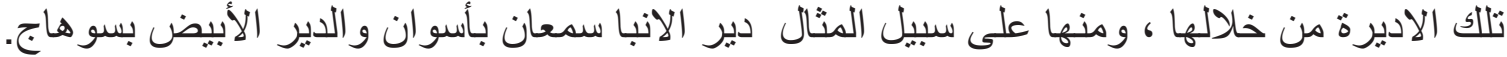

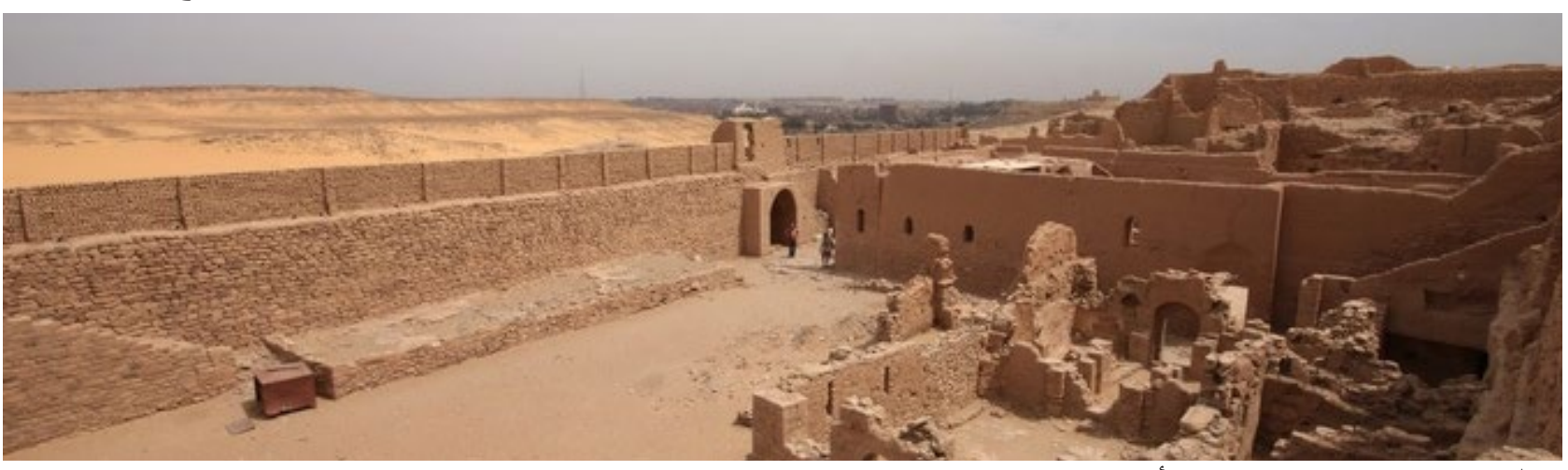

- The baptistery and the eastern entrance,2017 ISIDA.

شكل - 01 دير الانبا سمعان بأسوان

http://isida-project.org/egypt_april_2017/aswan_stsimeon_en.htm. 9 November 2020

دير الأنبا سمعان غرب أسوان ..

يمثل دير الأنبا سمعان شاهداً للعمارة القبطية ، ويعتبر الدير الوحيد المتبقي من الأديرة الباخومية ، ويرتاده

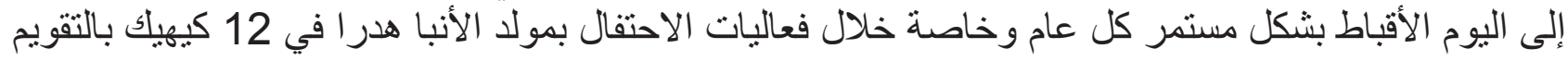

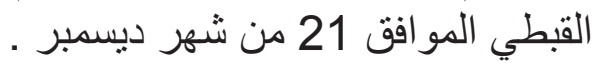

تاريخ بداية الدير غير مؤكدة ولكن اقدم آثار استيطان المنطقة تتمثل في شو اهد القبور الموجودة بالدير ونشير على الثى

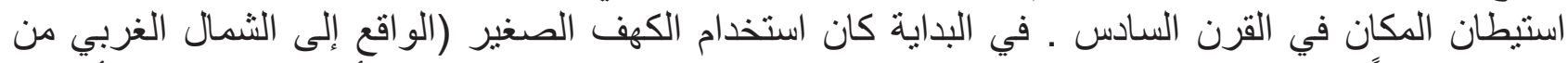

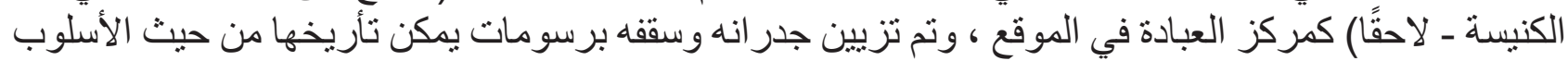

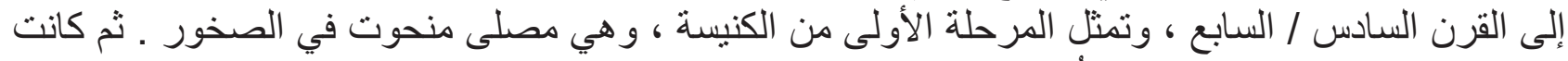

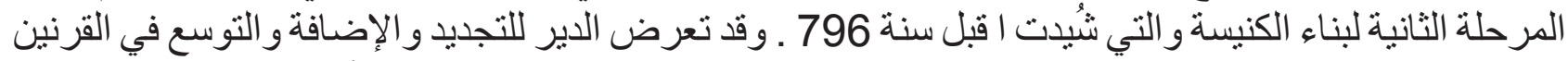

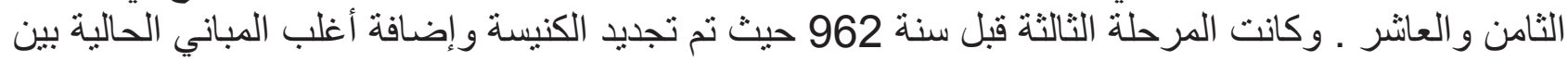
القرن العاثر و الحادي عشر كنوع من التوسعة للاير القديم ـ وفي القرن الثاني عشر / الثالث عشر كانت الثر الثرحلة

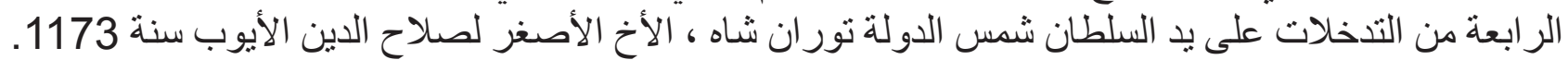

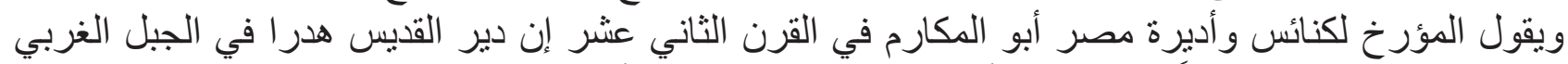

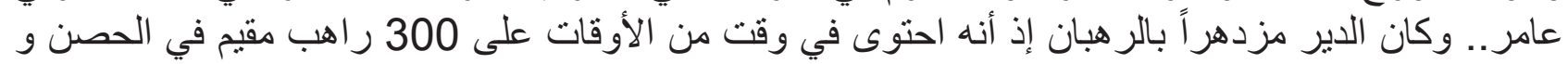

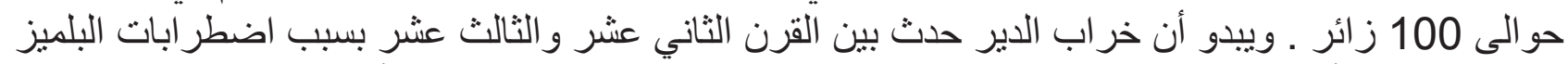

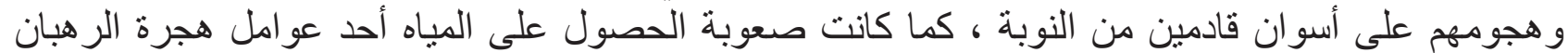

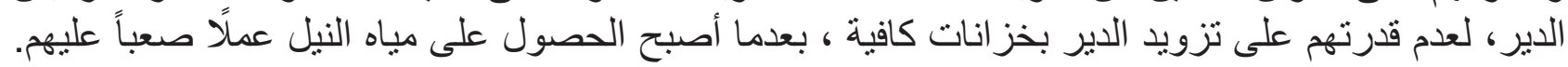

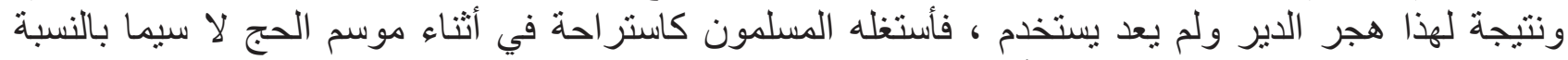

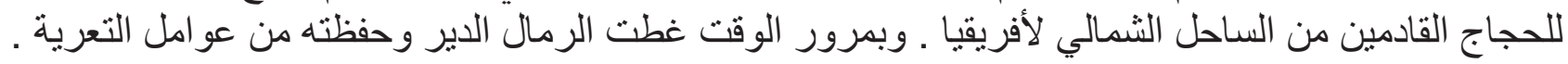



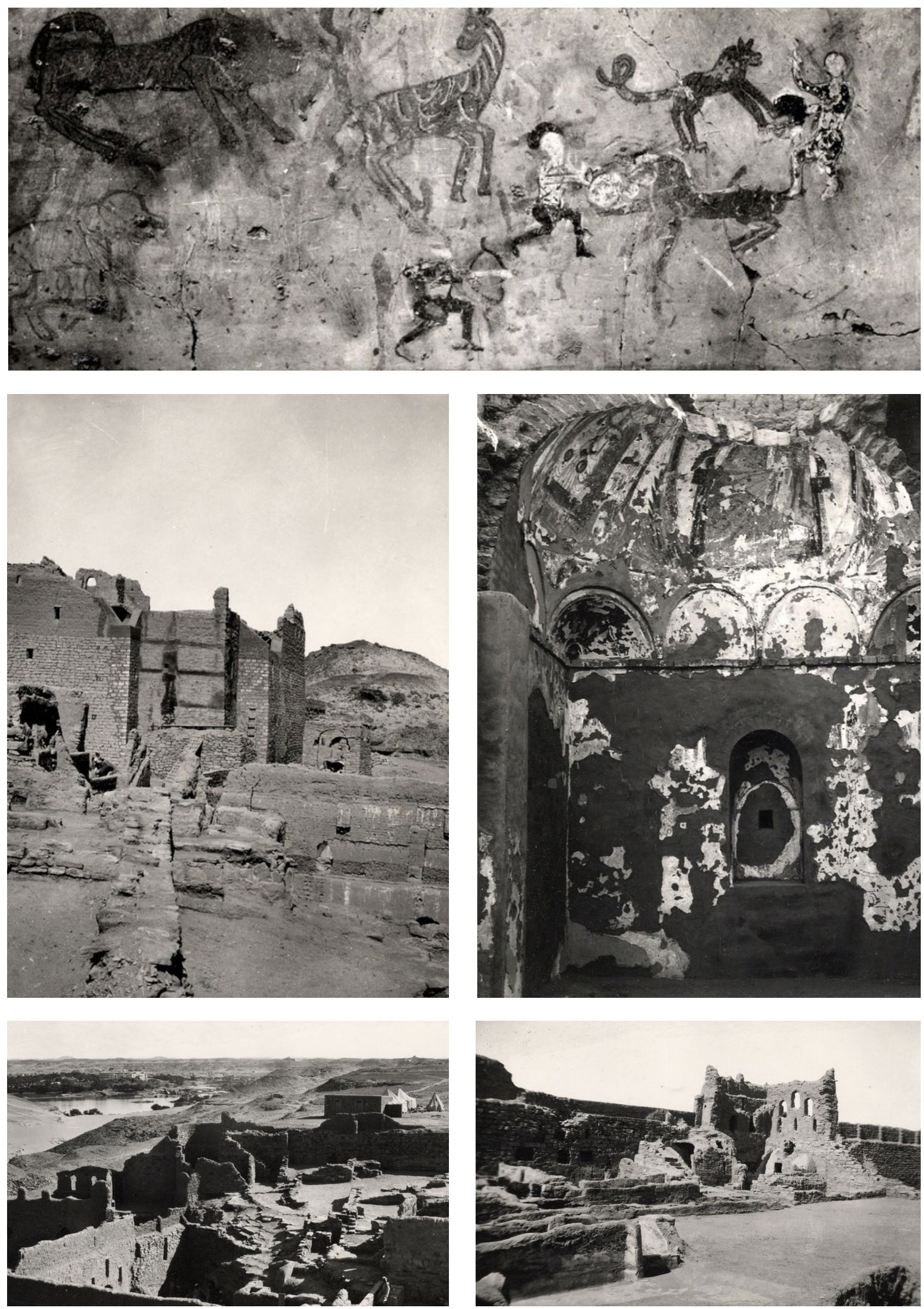

شكل - 02 صور تاريخية لدير الانبا سمعان في عشرينات القرن الماضي نقلا عن :

Istituto Centrale per il catalogo e la documentazione 
كانت أول خريطة ترسم للاير من عمل الأثري دي مورجان سنة 1893 ضمن مؤلفه لاكتالوج آثار وكتابات

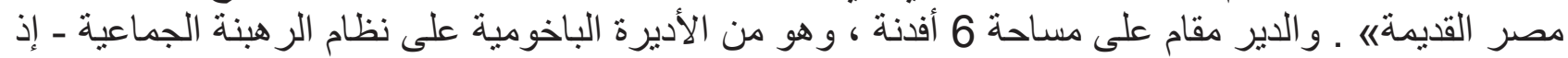

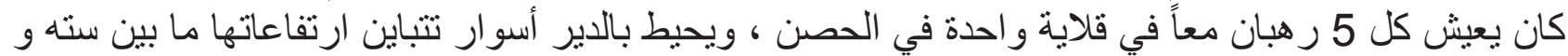

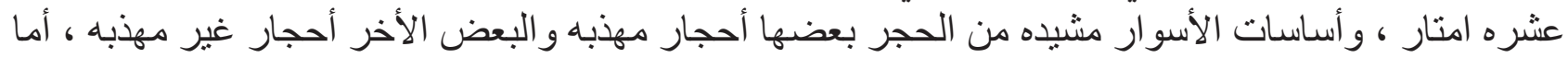

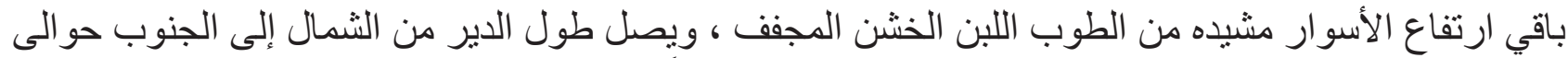

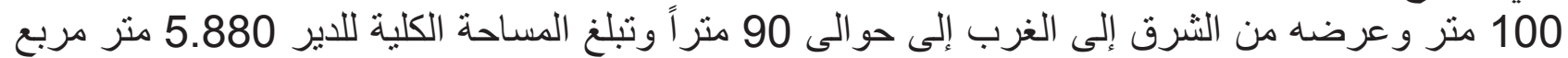
، وينقسم الدير إلى مستوبين (مصاطب طبيعية للمكان) ـ ويتكون الدير من باب رئيسي وسط وسط الحائط الشرقي

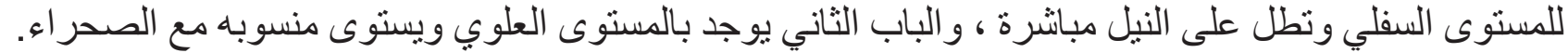

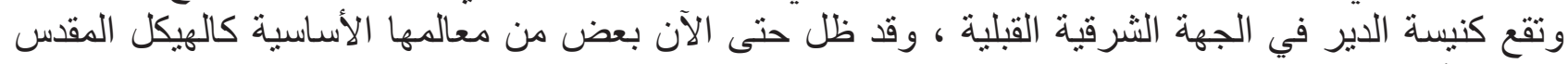
وقو اعد أعمدتها فقط ، وبعض آثنار من الصور التي رسمت في عصر نهضتها مع بعض الحجرات الجانبية ؛

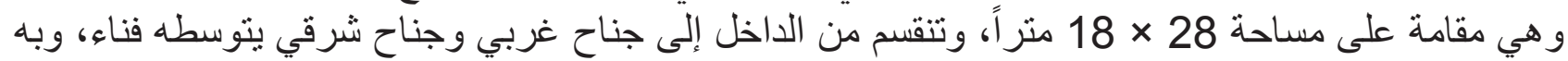
الهيكل الرئيسي على شكل صليب على جانبيه حجر ات ات ، يوجد بهذا الهيكل رسومات جدارية تمثل أيقونات للسيدة العذر اء و القديسين ماز الت آثار ها موجودة ـو ـ و الدير كان يضم منطقة القلالي و الحصن ، و والطاحونة و الأفران

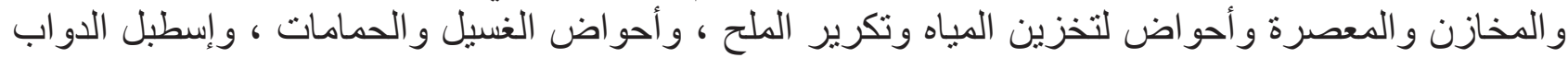

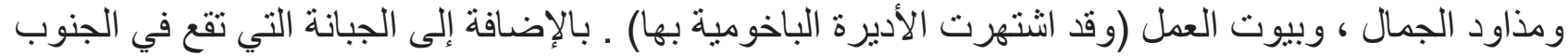

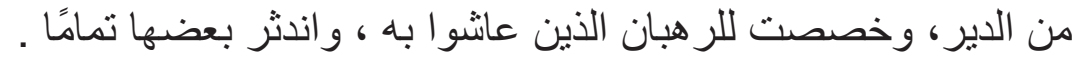

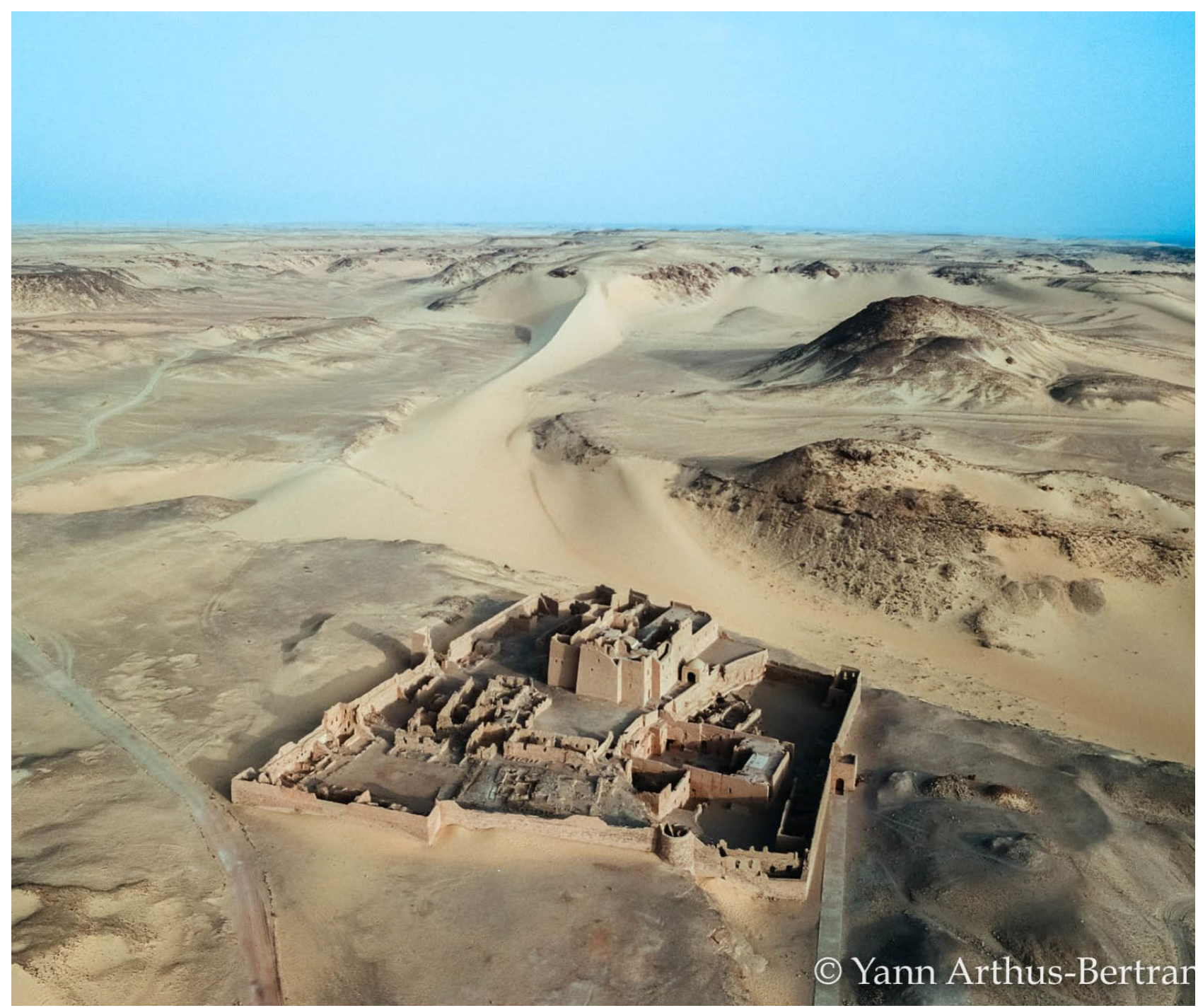




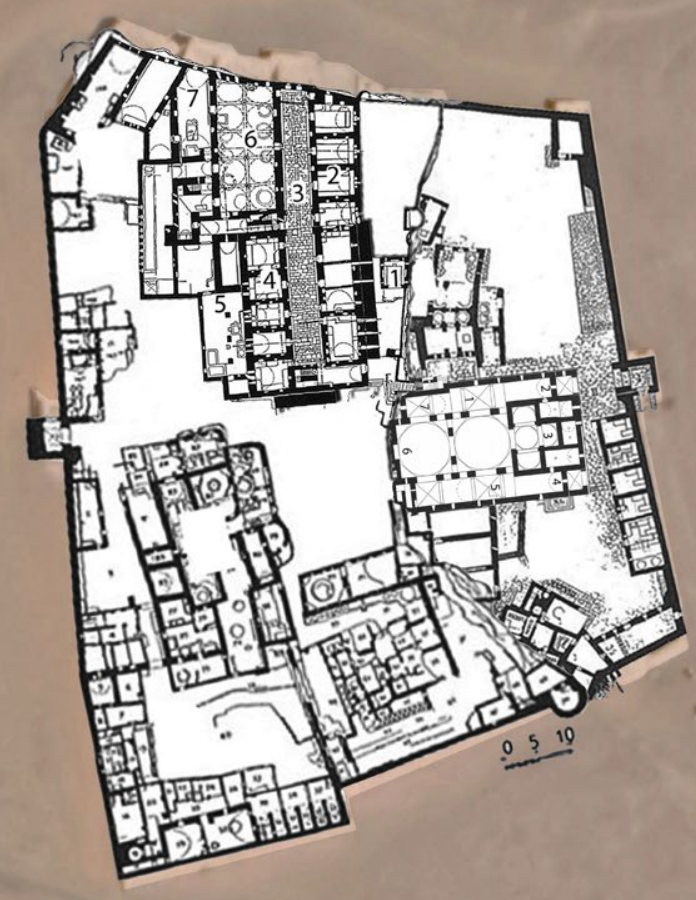

- The monastery plan as drawn by Monneret de Villard in "Monastére de Saint Siméon A'Aswan". Milan.1927 (as cited in St. Mark Foundation book)

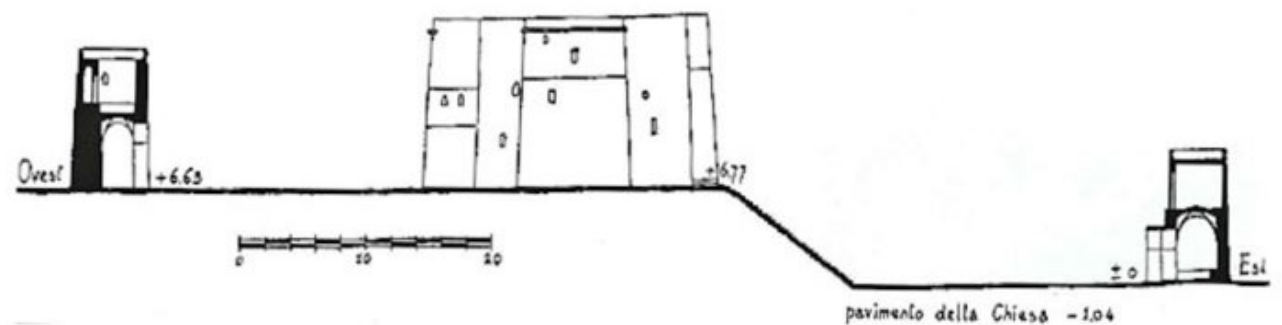

- The monastery section as drawn by Monneret de Villard in "Monastére de Saint Siméon A'Aswan". Milan.1927 (as cited in St. Mark Foundation book)
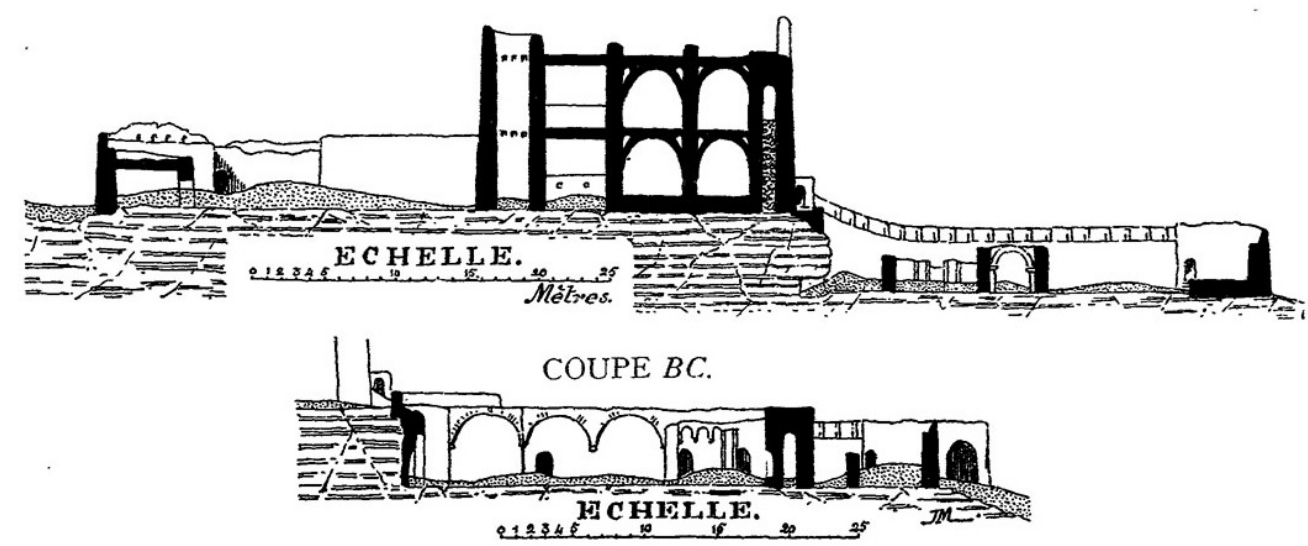

- The monastery section as drawn by Monneret de Villard in "Monastére de Saint Siméon A' Aswan". Milan.1927 (as cited in St. Mark Foundation book)

$$
\text { شكل - } 03 \text { نماذج من الرسومات المعمارية لدير الانبا سمعان }
$$




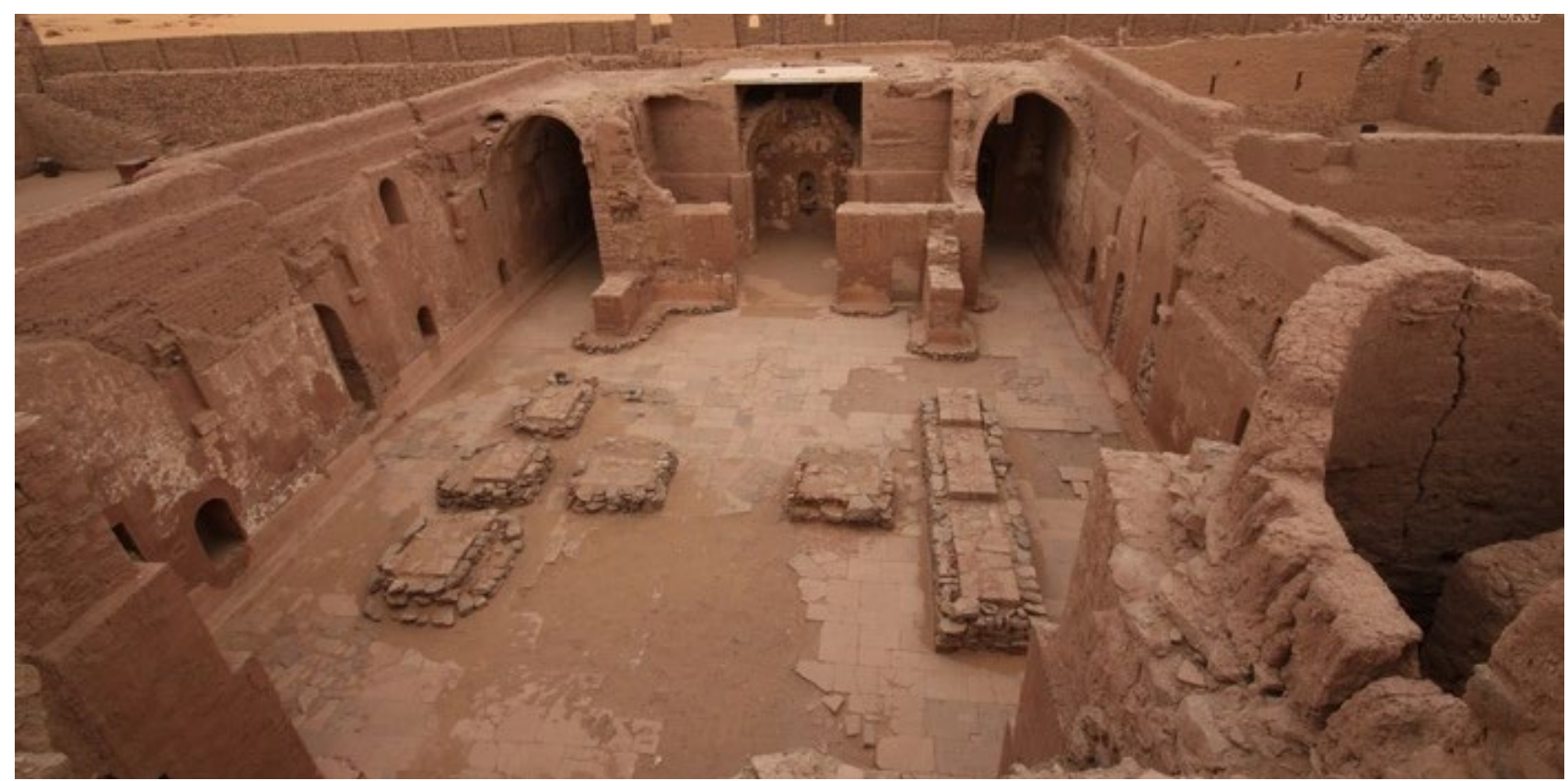

- The Church from the upper terrace ,2017 ISIDA.

http://isida-project.org/egypt_april_2017/aswan_stsimeon_en.htm. 9 November 2020

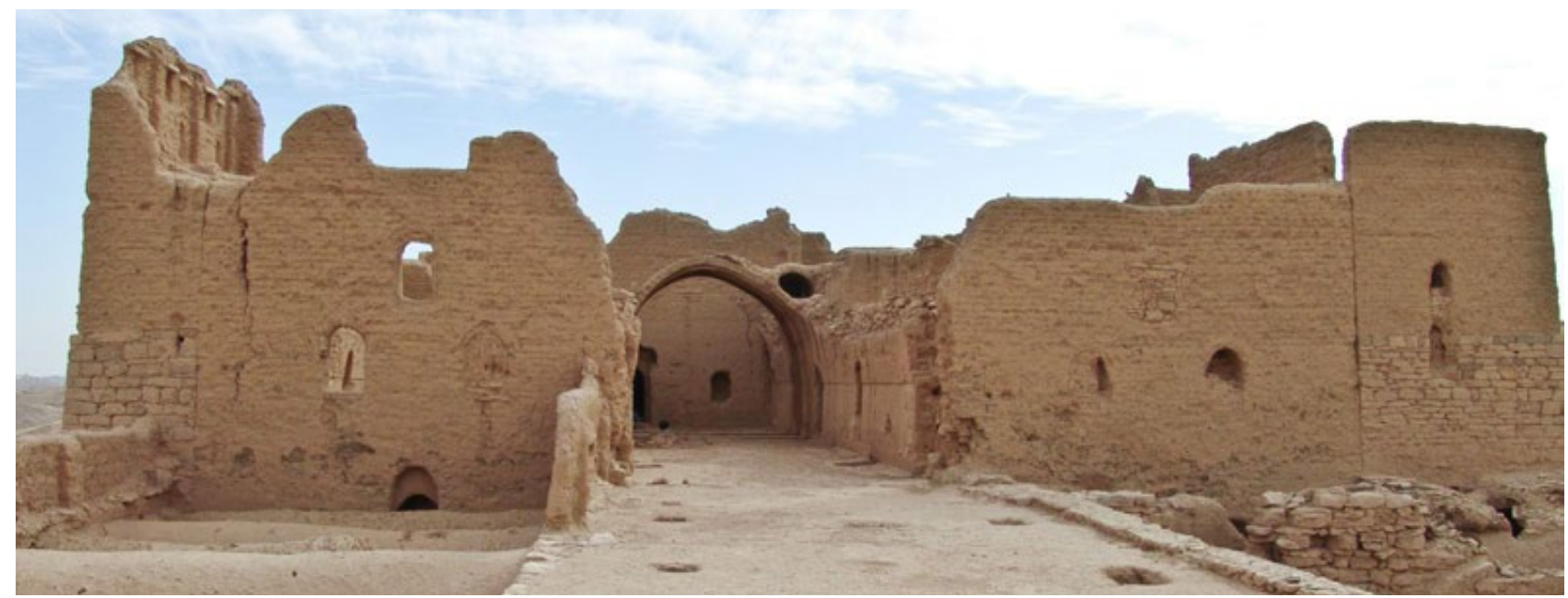

- A view of the Keep from the second floor, St. Mark Foundation, Aswan, Egypt 2011
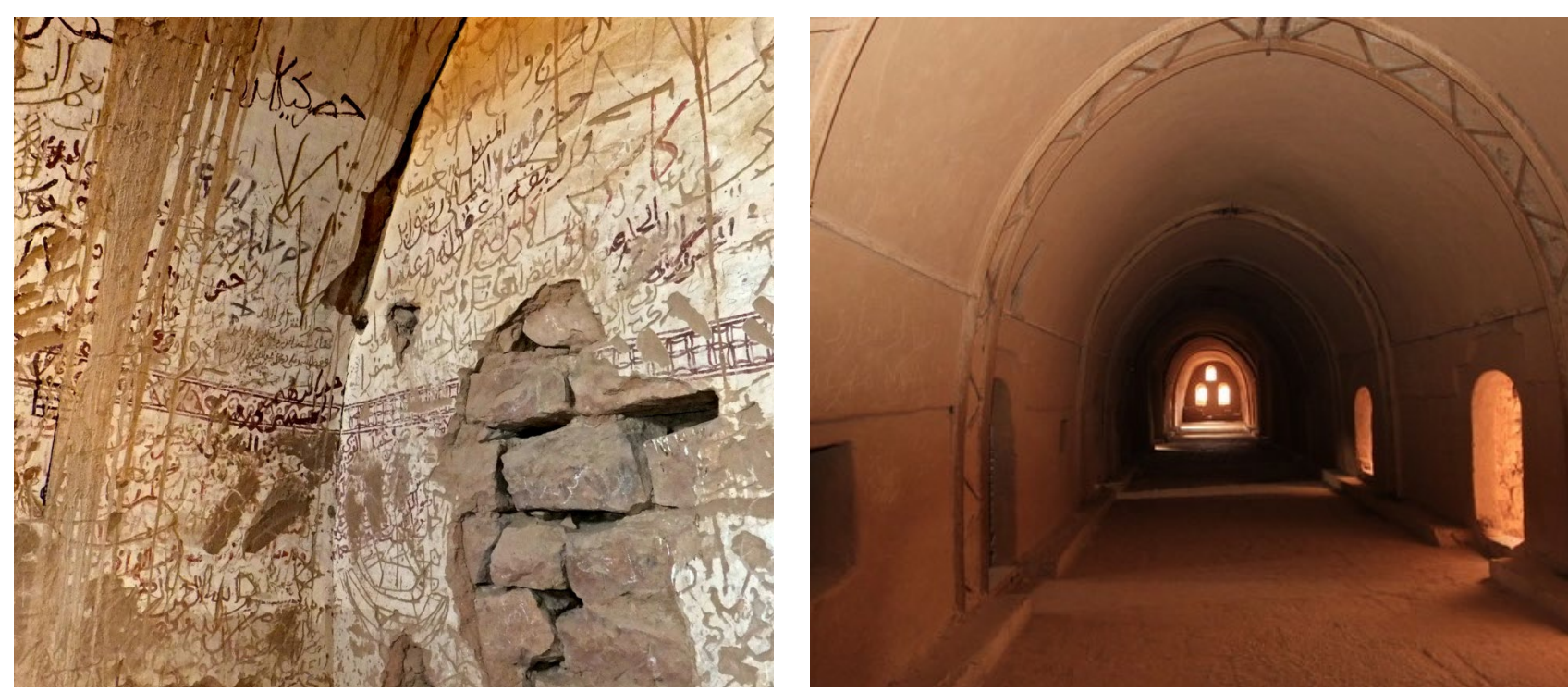

- The Keep ,2017 ISIDA. http://isida-project.org/egypt_april_2017/aswan_stsimeon_en.htm. 9 November 2020 شكل - 04 مور حديثة لدير الانبا سمعان 


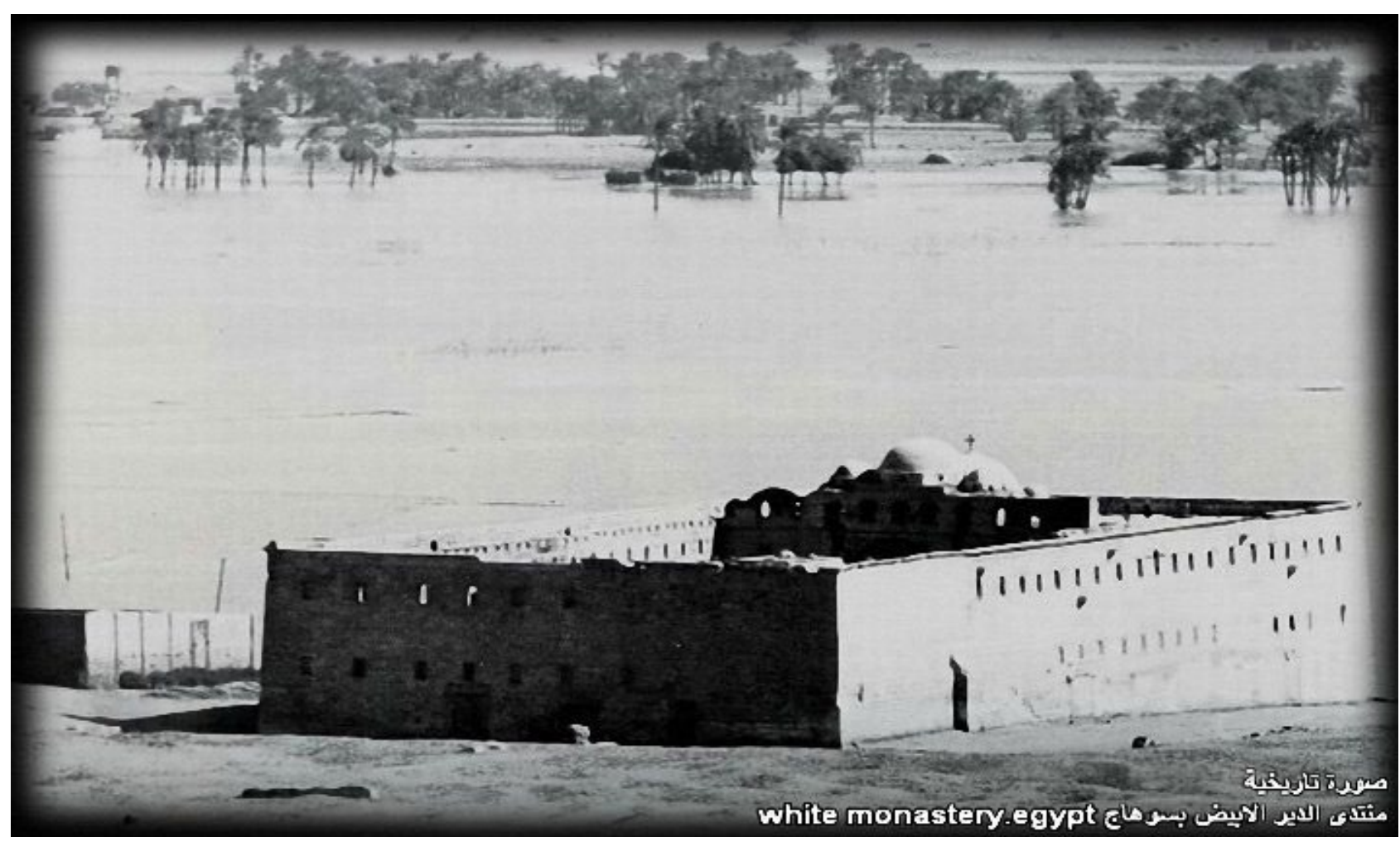

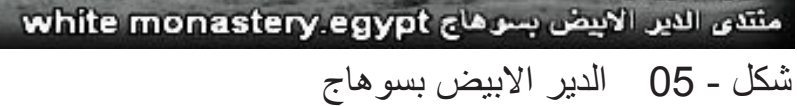
دير الأنبا شنودة أو الدير الأبيض .. سوهاج سواج

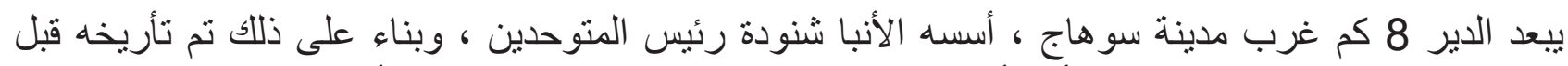

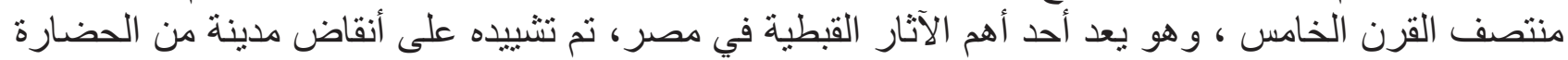

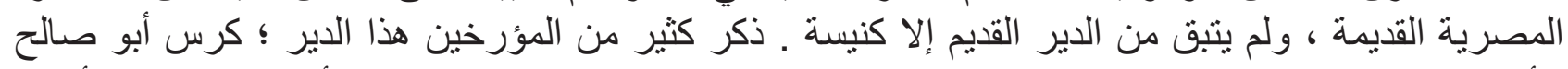

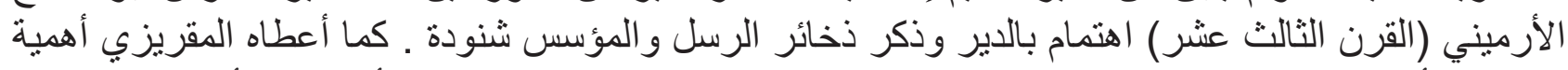

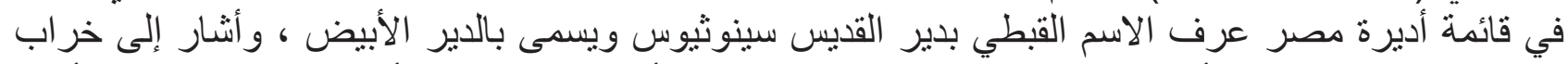

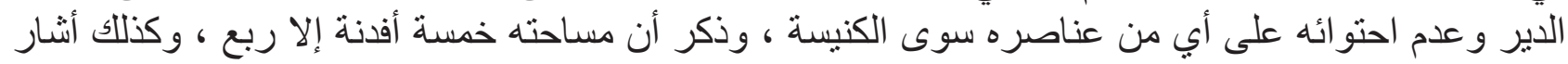

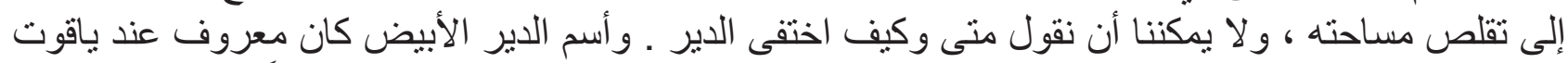

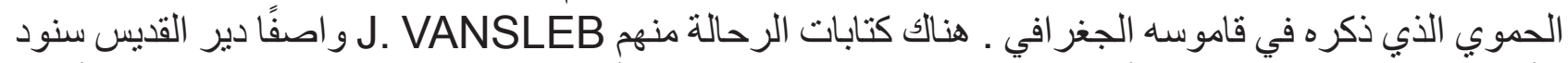

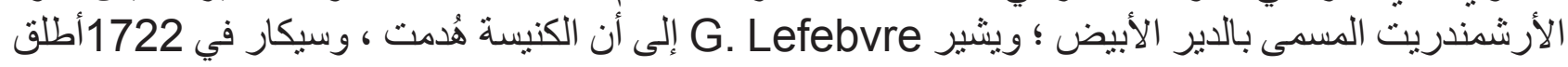

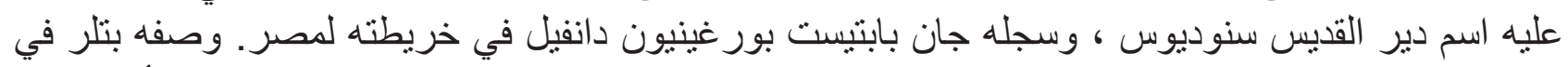

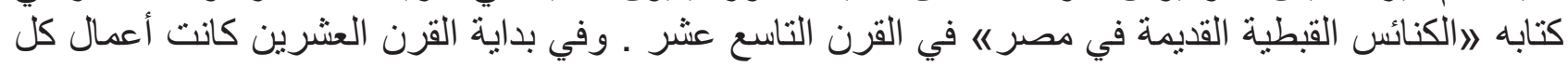

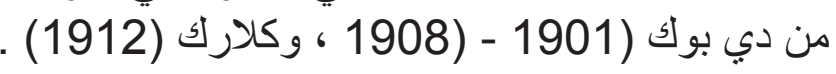

وصف عمارة الاير...

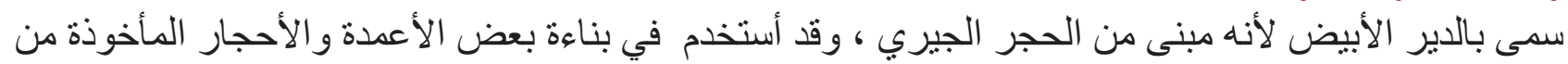

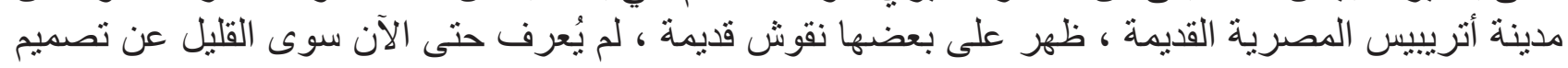

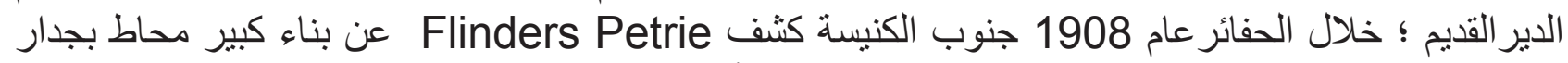

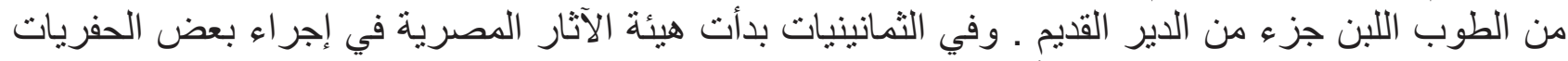

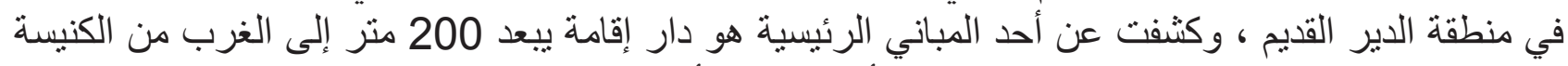

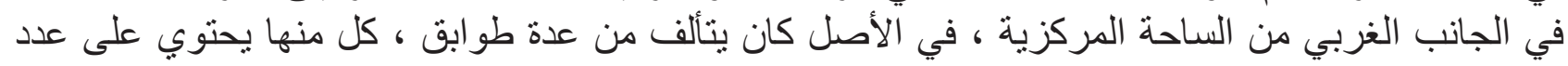

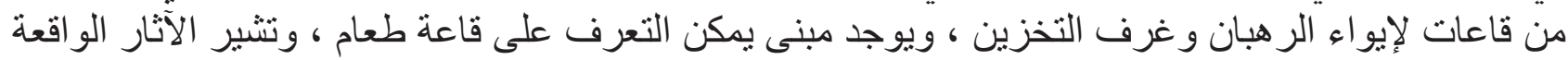

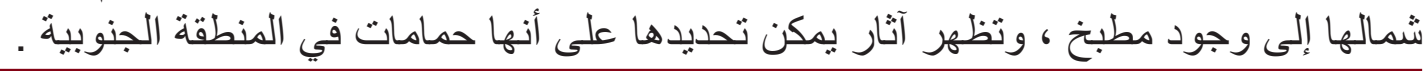



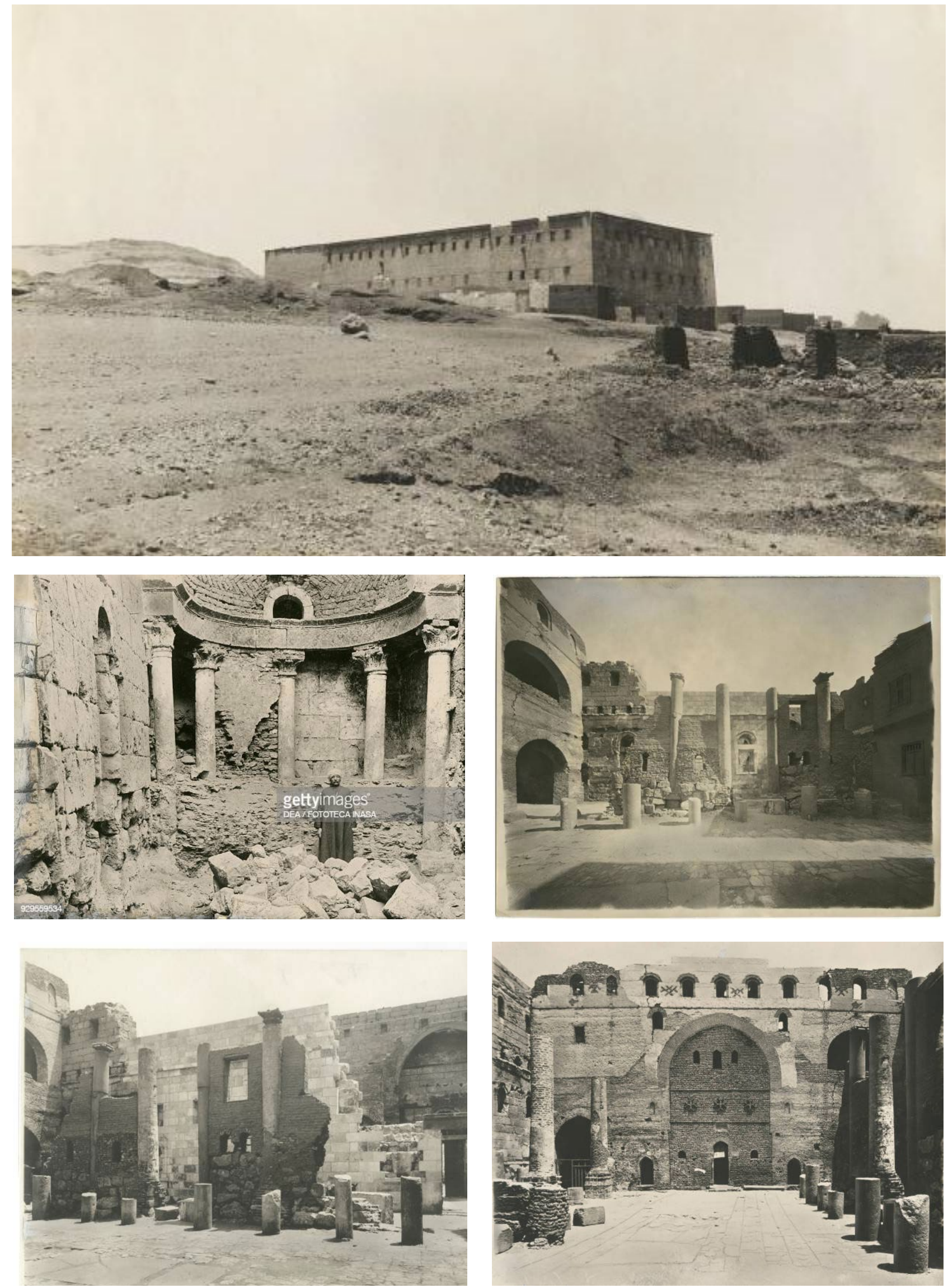

Getty Images نقلا عن ارشيف De Agostini صور تاريخية للاير الابيض في 1912 من مجموعة https://www.gettyimages.com 


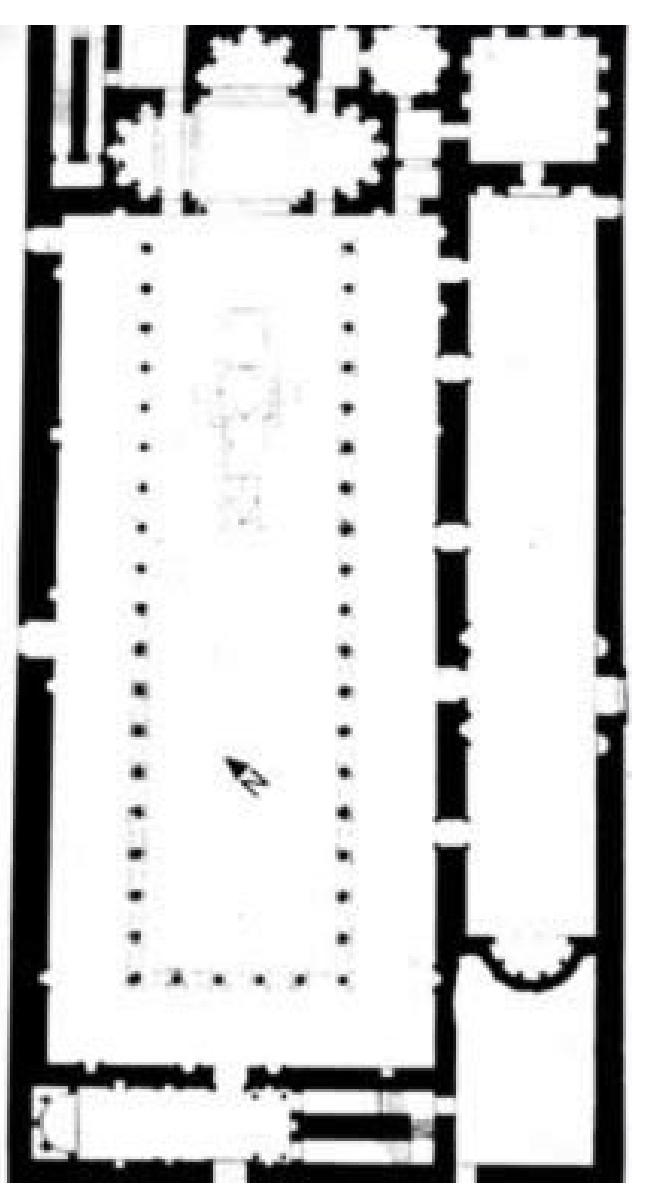

ويتبع تصميم كنيسة الدير أسس التخطيط البازيليكى ، إذ تمتد من الثرق إلى الغرب وتعتبر أهم أثر للعمارة القبطية المبكرة في صعيد

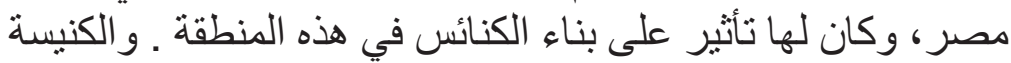

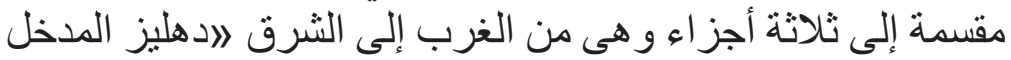

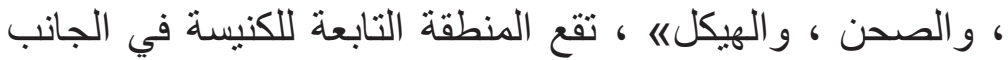

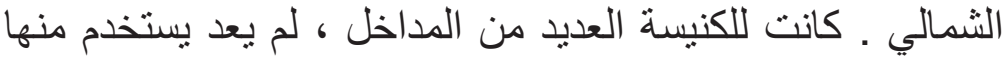

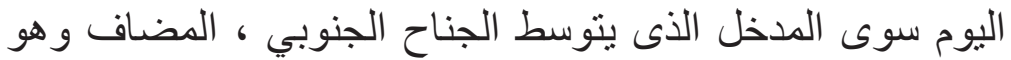

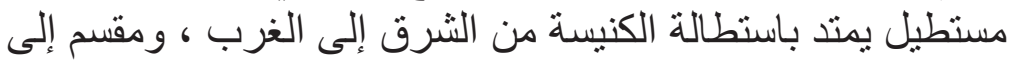

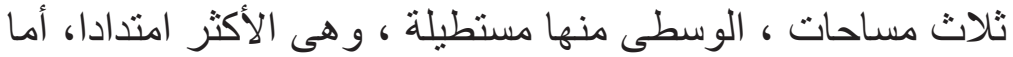

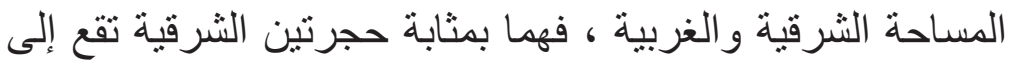

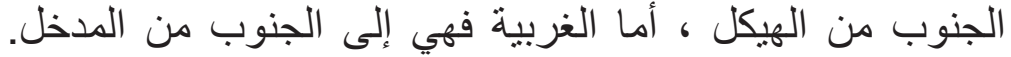

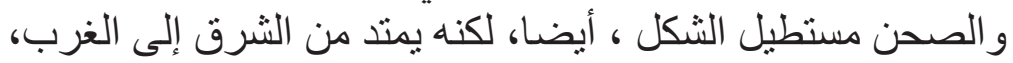

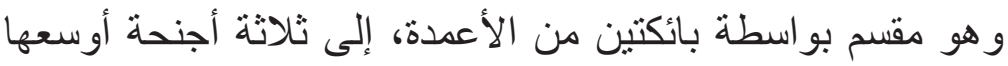

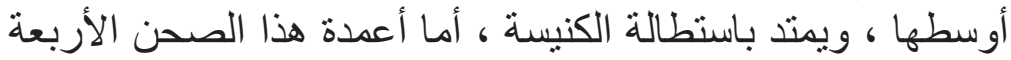

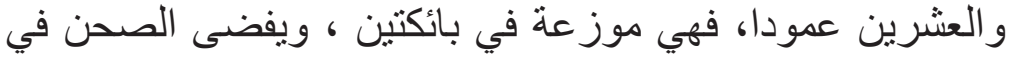

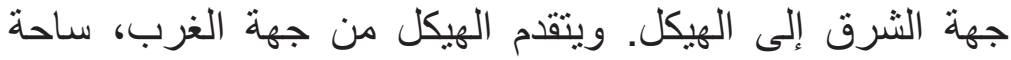

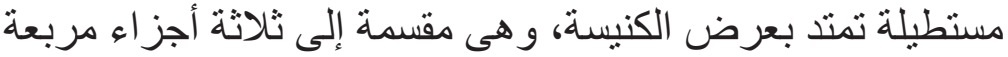

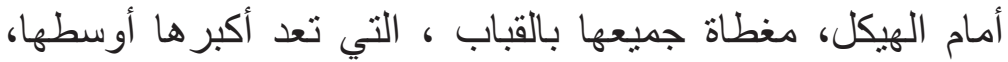

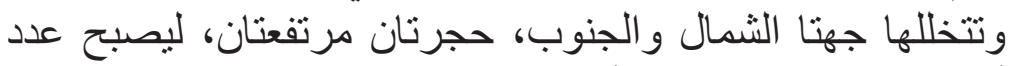
أجز اء هذه الساحة خمسة أجز اء.

شكل - 07 مسقط افقي لكنيسة الدير الابيض
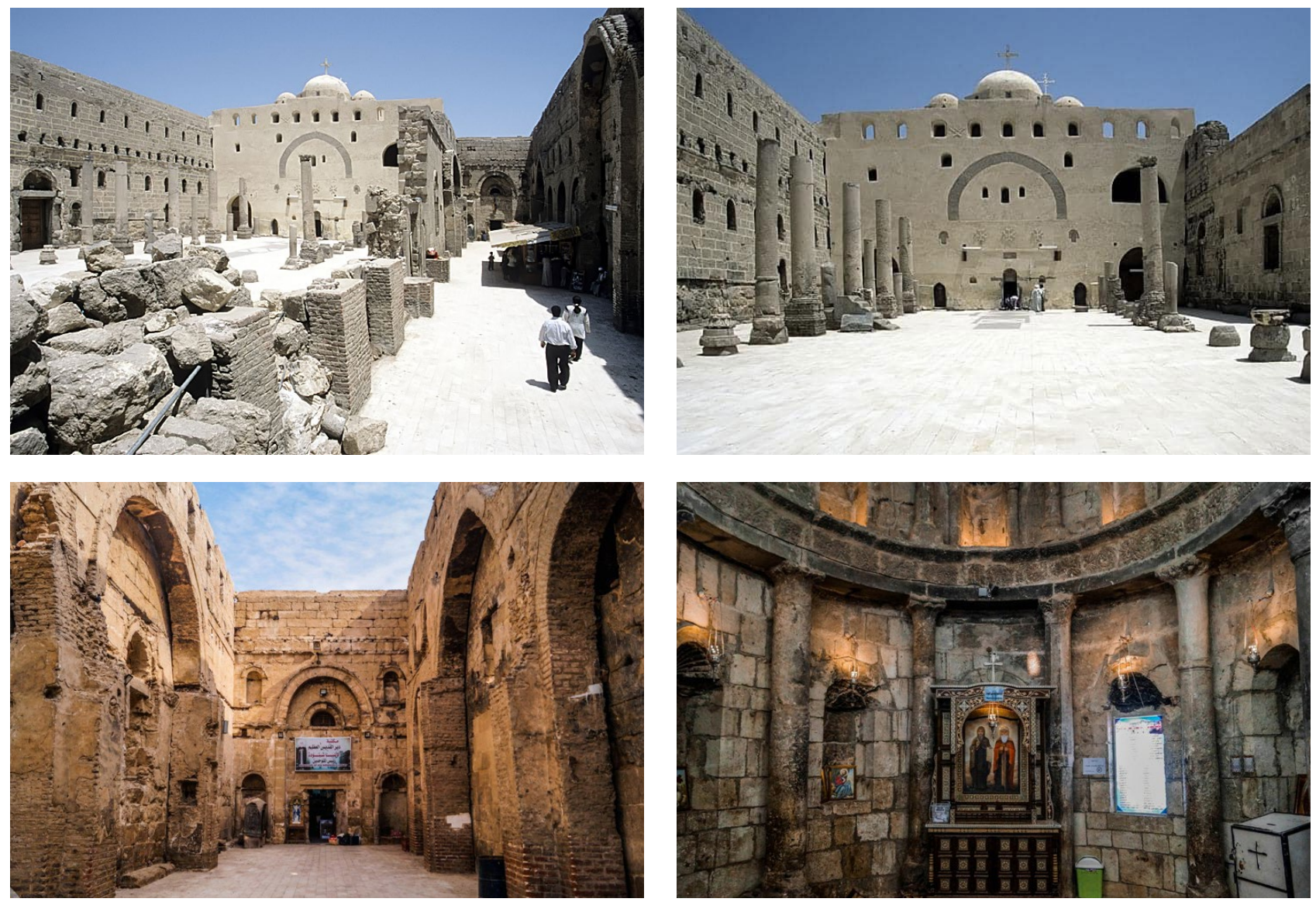

Wikimedia common شكل - 08 صور حديثة للاير الابيض في 2010 نقلا عن 


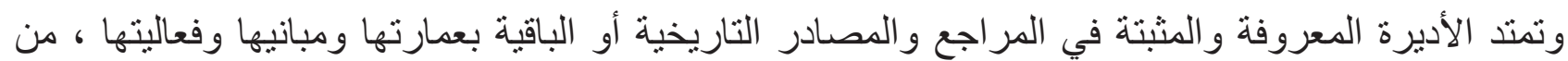
سواحل البحر الأبيض والإسكندرية شمالا حتى جنوب الصعيد وبلاد النوبة جنوبا ومن الواحات بالصحر اء الهاء

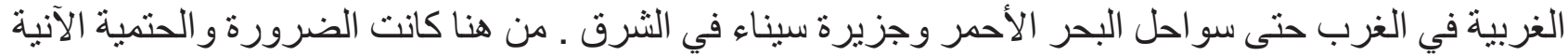
كخطوة أولى و أساسية هو بناء سجل معرفي لجمع شتات المعلومات المتاحة في كتب المؤرخين وكتابات الرحالة

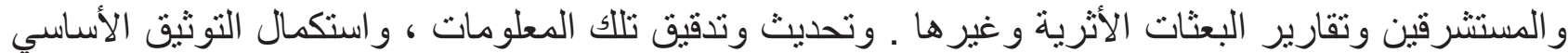

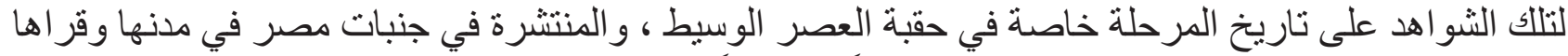

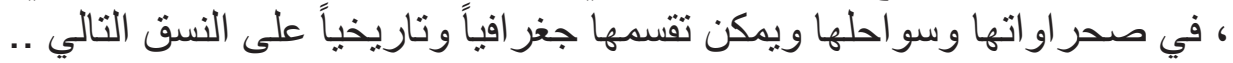
التقسيم التاريخي لتأسيس وبناء الأديرة

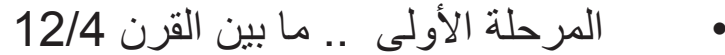

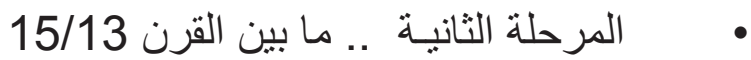

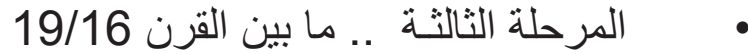

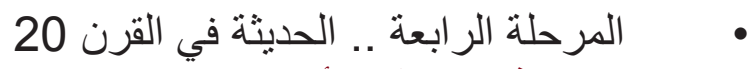

التقسيم الجغرافي لمواقع الأديرة

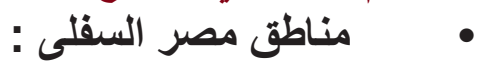

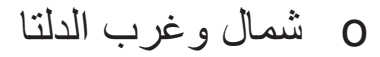

O

O شبه جزيرة سيناء

o

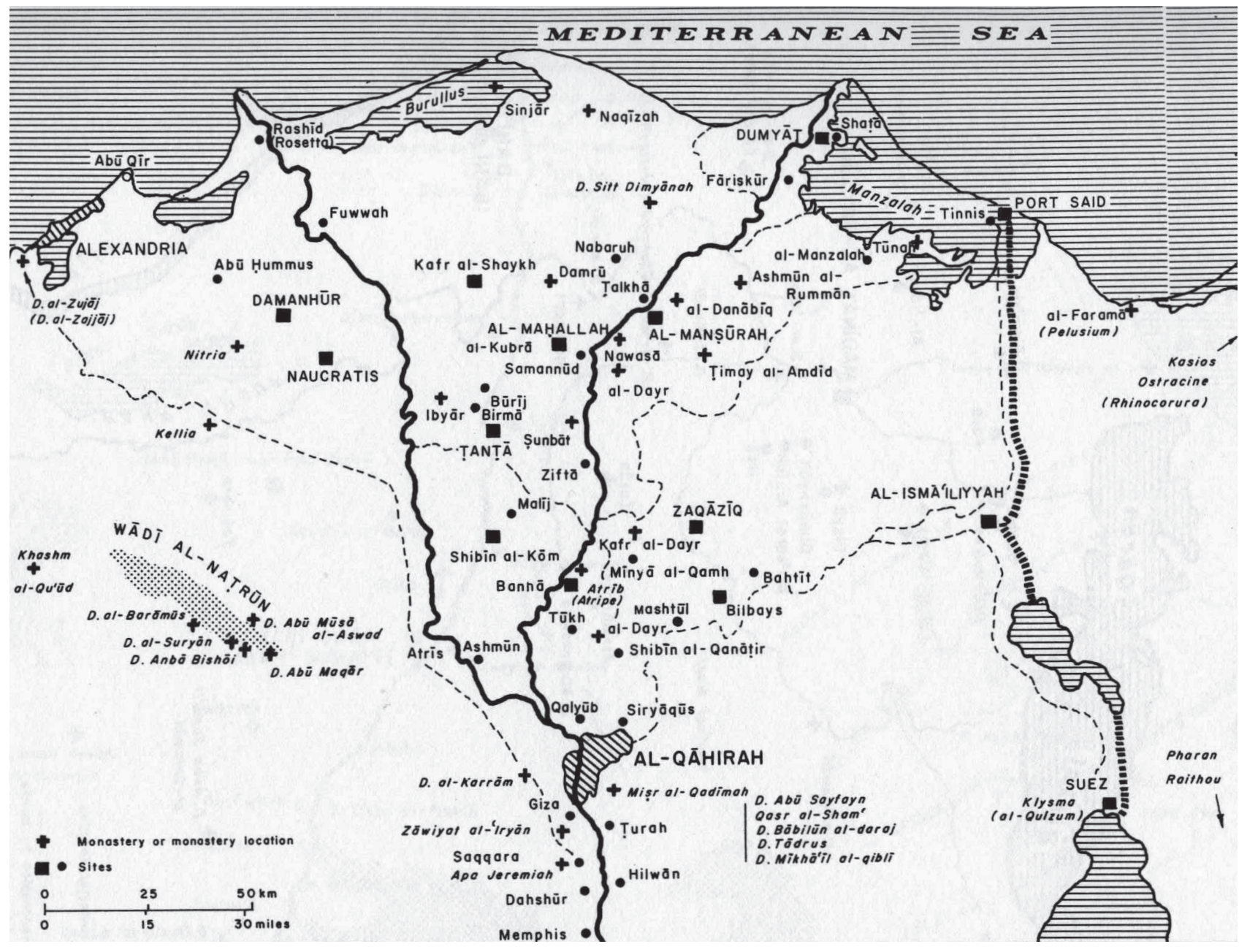

شكل - 09 خريطة اديرة الدلتا ، نقلا عن موسو عة كليرمونت القبطبة

Karen J. Torjesen and Gawdat Gabra, Claremont Coptic Encyclopedia, 2009 ,

available online at : https://ccdl.claremont.edu/digital/collection/cce 


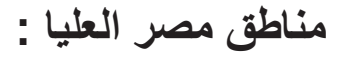

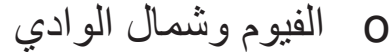

0

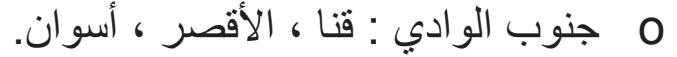

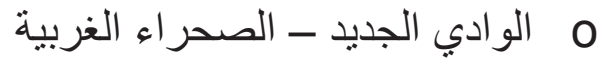
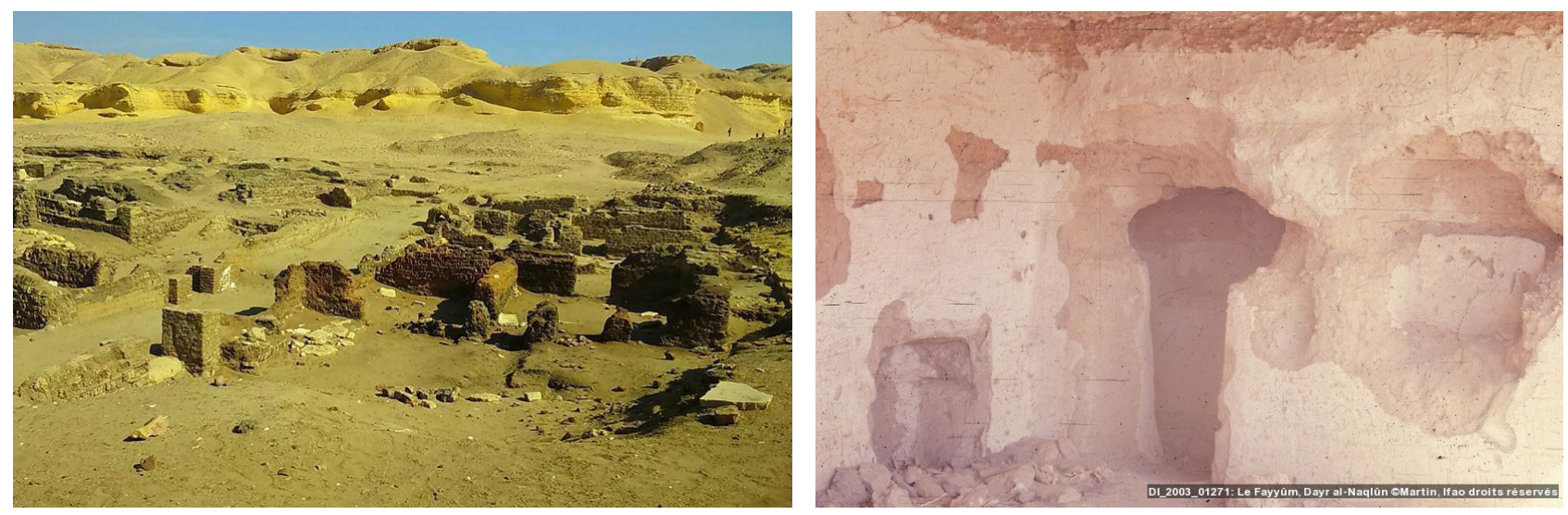

شكل - 11 خلوات الرهبان جبل النقلون بالفيوم

شكل - 10 دير النقلون بالفيوم

/https://www.ifao.egnet.net/bases/publications/bec23 نقلا عن ارشيف موريس مارن

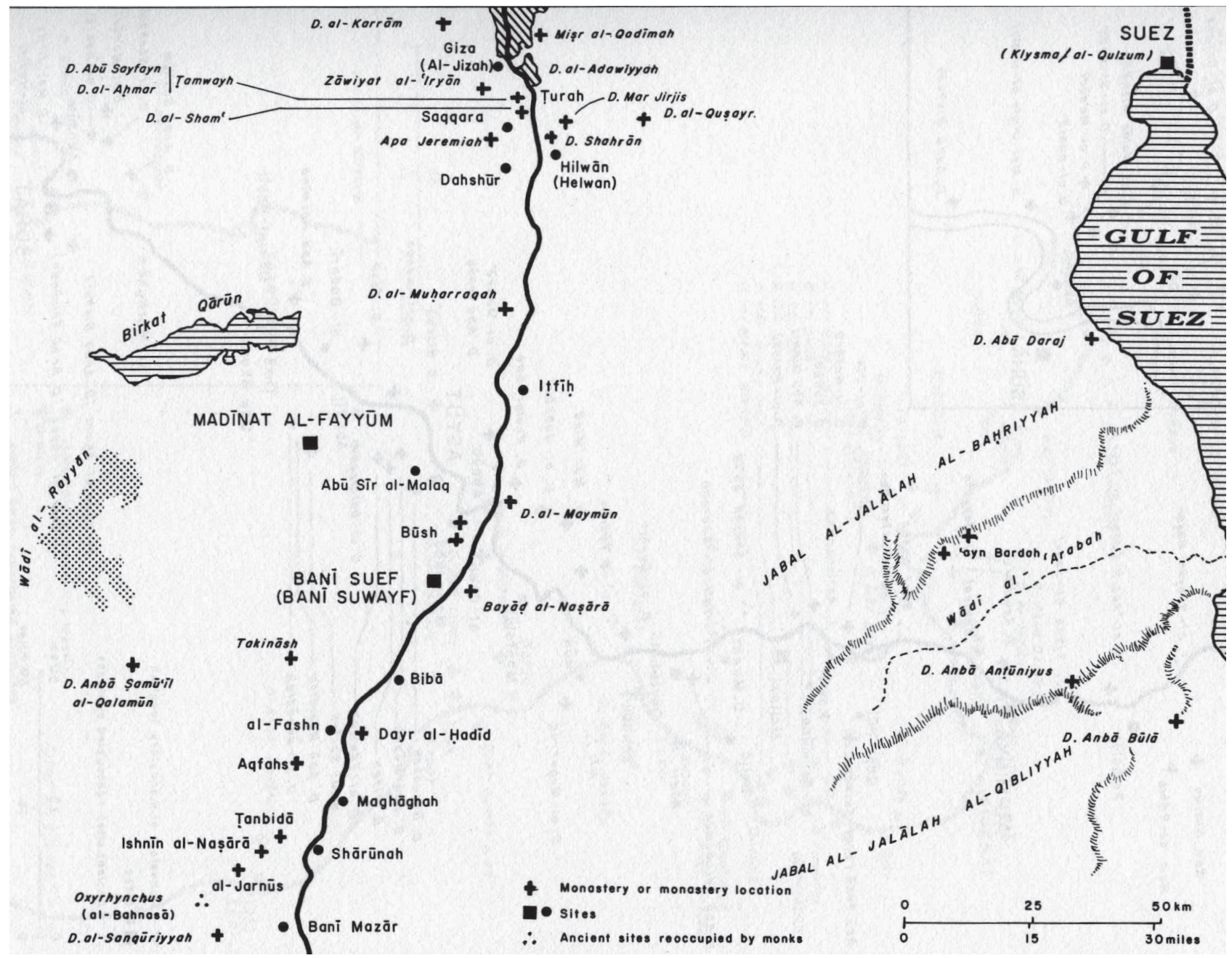

شكل - 12 خريطة اديرة الفيوم ، نقلا عن موسو عة كليرمونت القبطية

Karen J. Torjesen and Gawdat Gabra, Claremont Coptic Encyclopedia, 2009 ,

available online at : https://ccdl.claremont.edu/digital/collection/cce 

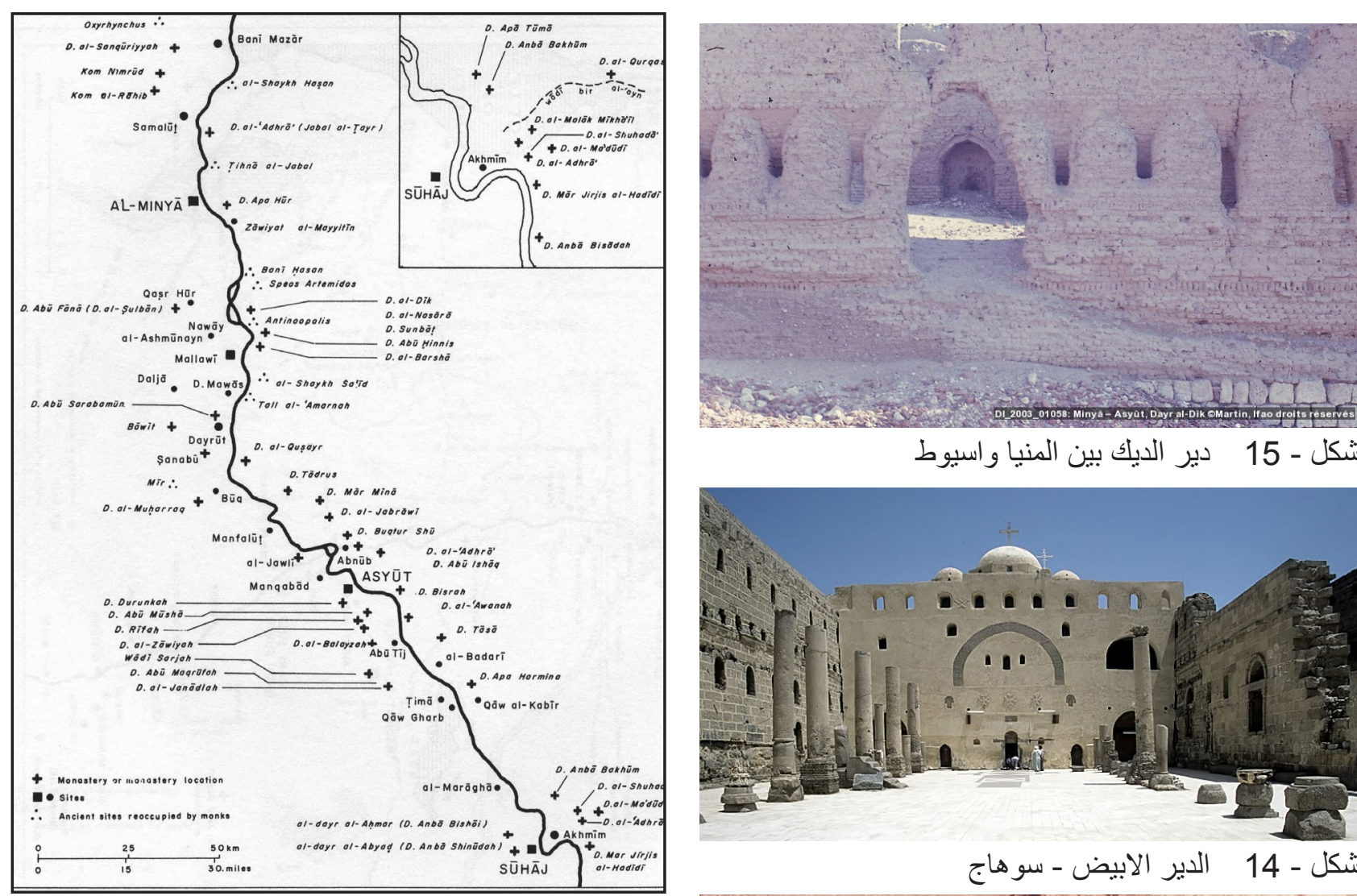

شكل - 15 دير الديك بين المنيا واسيوط

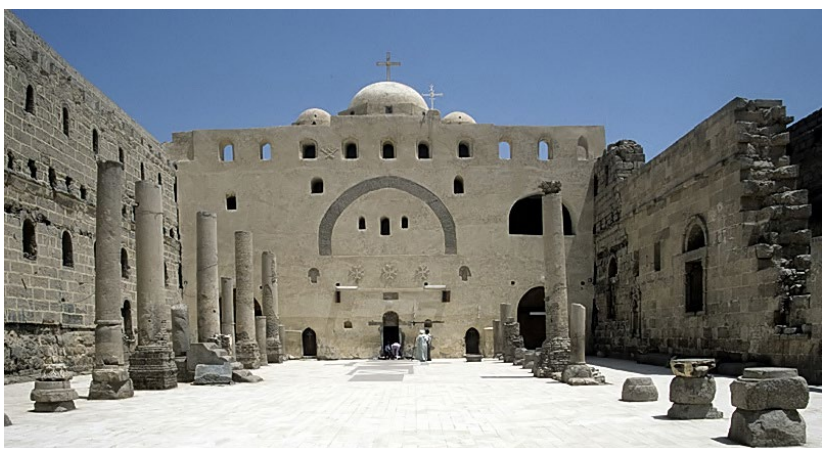

شكل - 14 الدير الابيض - سوهاج
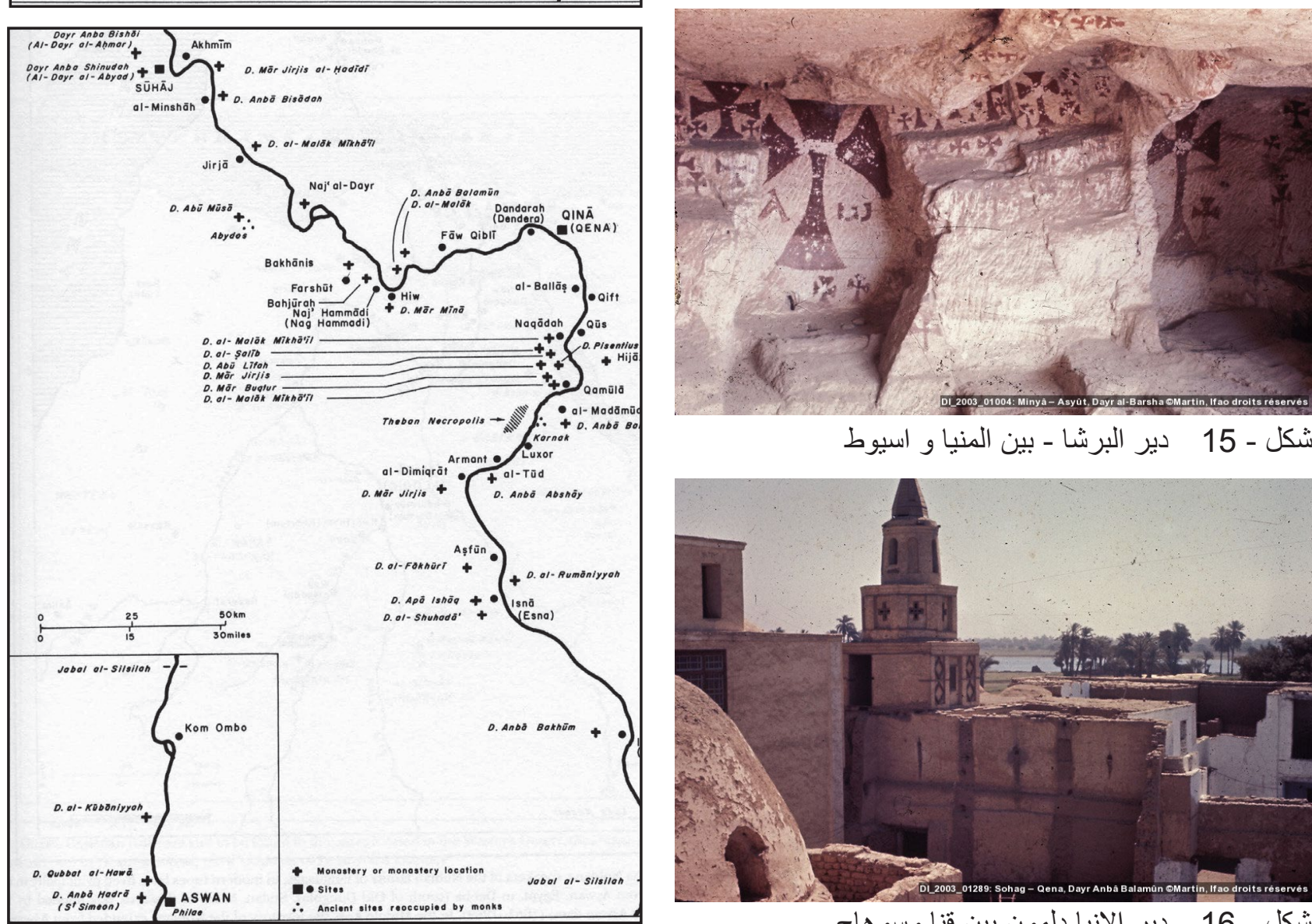

شكل - 15 دير البرشا - بين المنياو اسيوط

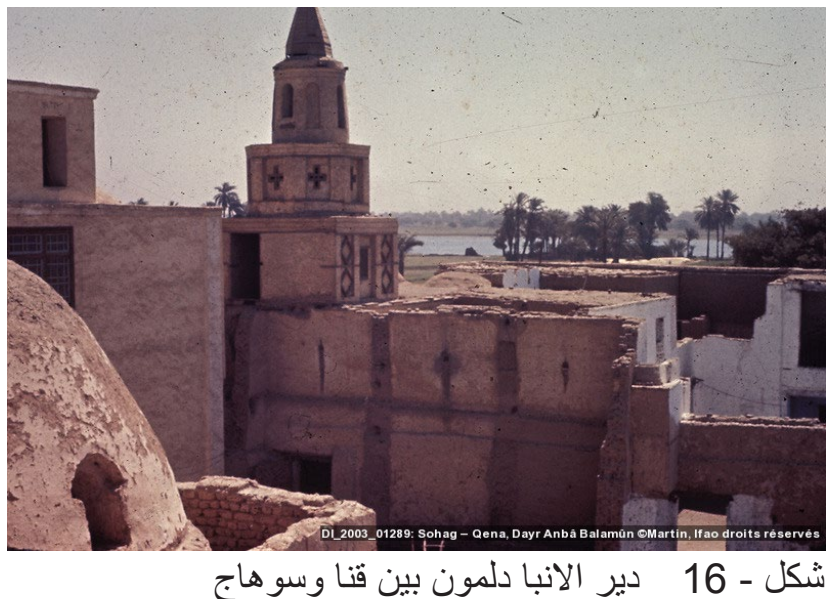

شكل - 17 خر ائط اديرة الصعيد ، نقلا عن موسوعة كلير مونت القبطية

https://www.ifao.egnet. نقلا عن ارشيف موريس مارنين /net/bases/publications/bec23 Karen J. Torjesen and Gawdat Gabra, Claremont Coptic Encyclopedia, 2009 , available online at : https://ccdl.claremont.edu/digital/collection/cce 


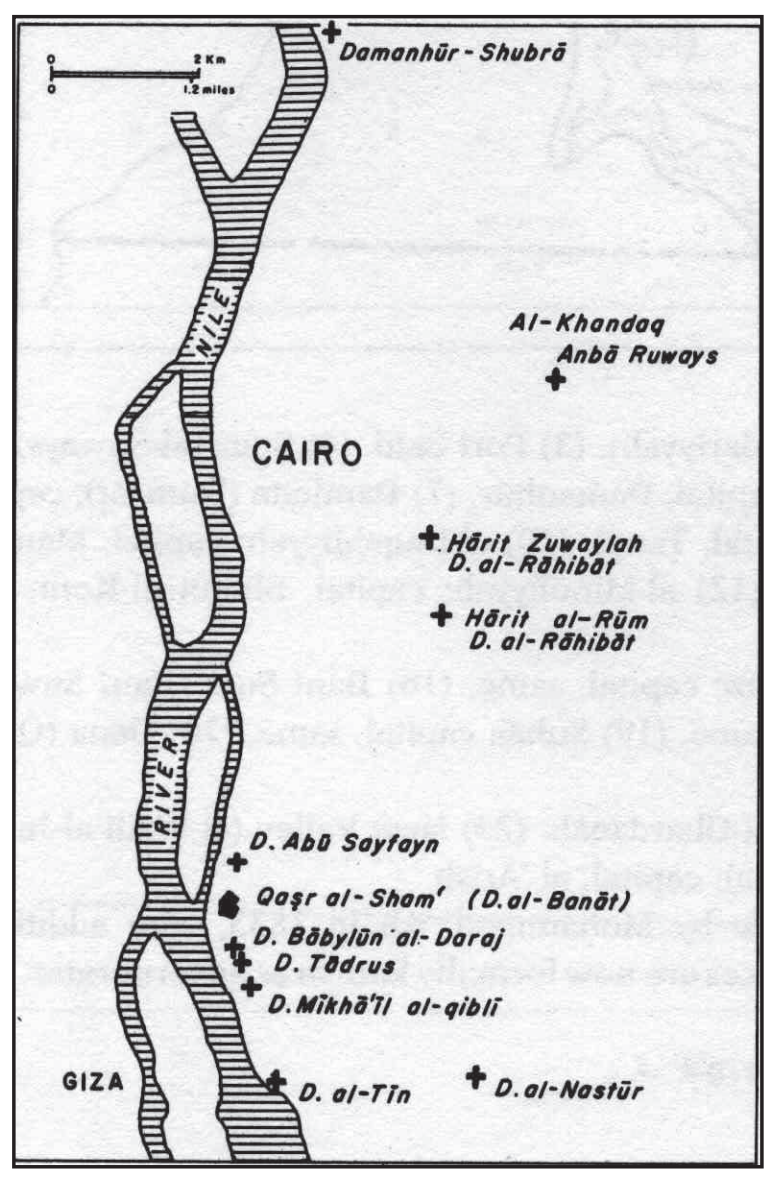

شكل - 18 خريطة الاديرة بالقاهرة

Karen J. Torjesen and Gawdat Gabra, Claremont Coptic Encyclopedia, 2009 , available online at : https://ccdl. claremont.edu/digital/collection/cce

\section{ويهاف هذا المشروع التوثيقي إلى ...}

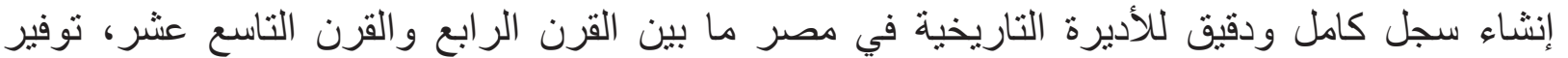

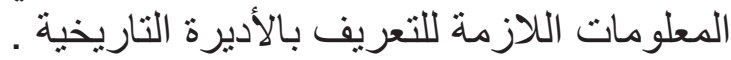

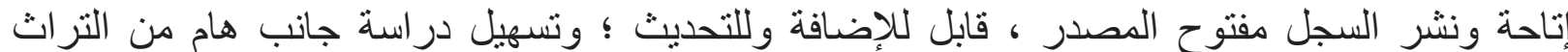

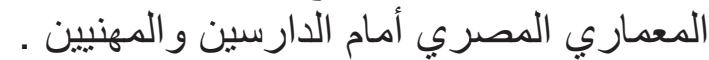

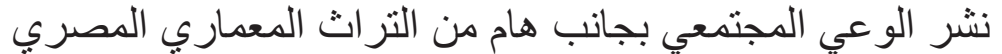

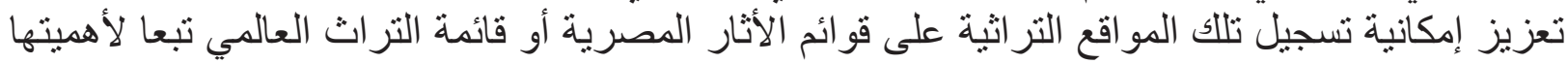

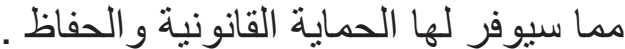
توفير المعلومات التي تساعد على در اسة تاريخ و عمارة الأديرة المصرية ومو اد وتقنيات بنائها في مر احلها

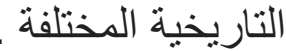
ت توفير سبل الحماية و الحفاظ اللازمة لتلالك الأديرة وتعزيز أدارتها كمو اقع تر اثثية .

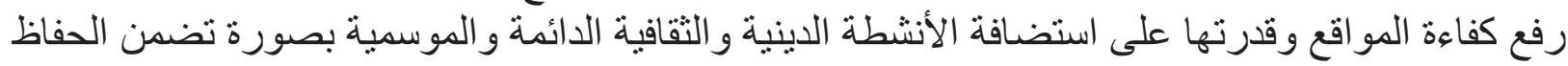

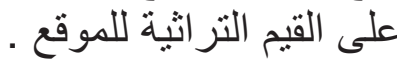
توفير أداة لتحقيق التكامل بين المؤسسات المختلفة ـ الثقافية و المهنية و التعليمية و الدينية ـ المعنية بالأديرة

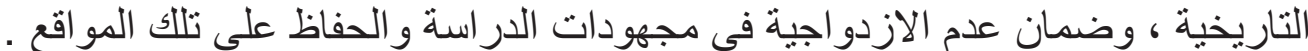

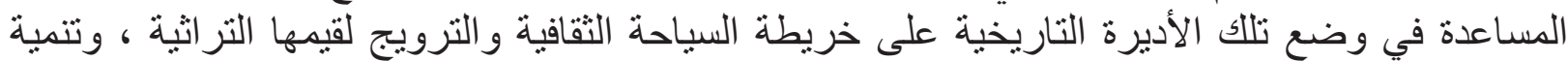

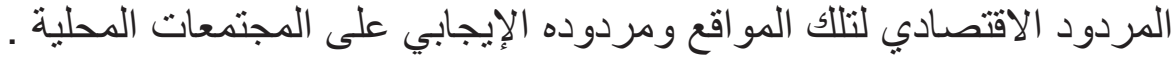


وفي سياق المشروع وبالاعتماد على مجموعة من المصادر الثانوية والادبيات جرى وضع قائمة مبلئية بالأديرة التاريخية في مصر ، وجمع المعلومات الاساسية عنها ـ بعض المعلومات لا نز ال غائ غير مؤكدة او غير معروفة ولكن تمثل القائمة بداية لانشّاء سجل الاديرة القبطية في مصر بصورة شمولية ، وفيما يلي القائمة المبدئية :

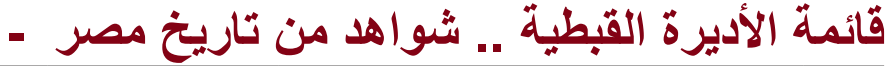

\begin{tabular}{|c|c|c|c|c|}
\hline ملاحظــــــات & 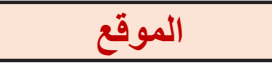 & تاريخ التأسيس & أسم الدير & ? \\
\hline 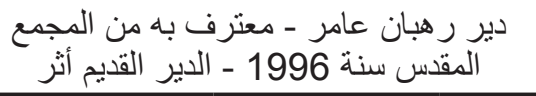 & 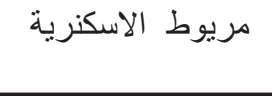 & تأسس 363 & 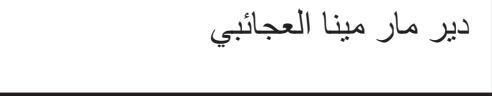 & 1 \\
\hline دير اليعاقبة & خارج الاسكندرية & تأسس 568 & دير الزجاج & 2 \\
\hline اطلال خلايا رهبان & خارج الاسكندرية & القرن 4 & قلالي الر هبان & 3 \\
\hline اطلال خلايا رهبان & خارج الاسكندرية & القرن 6-7 & 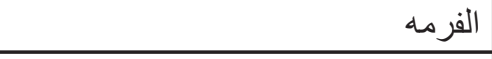 & 4 \\
\hline دير رهبان - اطلال جبل قلالي بالبحيرة أثنار & جبل القلالي البحيرة & تأسس 335 & دير القديس مكاريوس السكندري & 5 \\
\hline 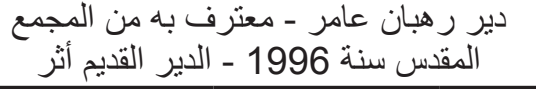 & و ادي النطرون & القرن & دير السيدة العذراء (البراموس) & 6 \\
\hline دير رهبان عامر - 1996 - الدترف به القديم أثريم & وادي النطرون & القرن 4 & دير القديس مكاريوس (ابو مقار) & 7 \\
\hline 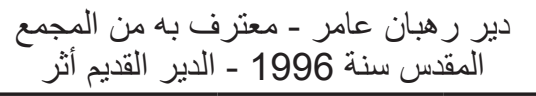 & و ادي النطرون & القرن & دير القديس الأنبا بيشوى & 8 \\
\hline دير رهبان عامر - 1996 - الديرف بله من القيم أثرع & و ادي النطرون & القرن 5 & دير السيدة العذراء (السريان) & 9 \\
\hline 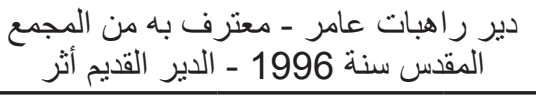 & مصر القديمة & القرن & 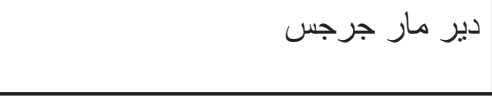 & 10 \\
\hline 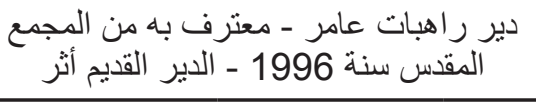 & مصر القديمة & 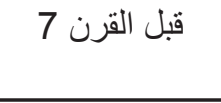 & دير مارقريوس أبى سيفين & 11 \\
\hline دير راهبات - دير اليعاقبة & مصر القديمة & & دير المعلقة & 12 \\
\hline دير راهبات - دير اليعاقبة & مصر القديمة & & دير بربارة & 13 \\
\hline دير رالهبات سنة 1996 ـ الكنبيسة أثر المجمع & حارة زويلة & 352 & دير السيدة العذراء & 14 \\
\hline دير راهبات عامر - معترف به من المجمع 1996 من & حارة زويلة & قبل القرن 12 & دير مار جرجس & 15 \\
\hline دير راهبات عامر - معترف به من المجمع 1996 مقدس & حارة الروم & قبل القرن 13 & دير الأمير نادرس & 16 \\
\hline دير راهبات - دير اليعاقبة & 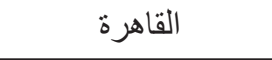 & & دير الر اهبات الفرنسيسكان & 17 \\
\hline دير راهبات - دير الملكانية & و وادي فيران سيناء & القرن الر ابع & دير البنات (بوجرج) & 18 \\
\hline الباقي من مباني الدير الكنيسة الثرية & المعصرة حلوان & قبل القرن 12 & دير الأنبا برسوم العريان & 19 \\
\hline رحلة العائلة المقدسة ـ أطلال وبقايا أثار & المعادي & قبل القرن 12 & دير السيدة العذراء (العدوية) & 20 \\
\hline دير اليعاقبة ـ تجديد وترميم الدير القديم & 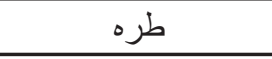 & قبل القرن 12 & دير جرج ( مار جرجس ) & 21 \\
\hline دير اليعاقبة & 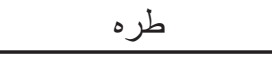 & قبل القرن 12 & دير شهران (دير الأنبا برسوم العريان) & 22 \\
\hline دير الملكانبة - أطلال وبقايا & جبل طره & قبل القرن 10 & دير بخنس القصبر( الانبا أرسانبوس) & 23 \\
\hline دير الملكانية ـ أطلال & الطور سيناء & القرن السادس & ل الطير الطور & 24 \\
\hline دير اليعاقبة & & & دير بطرس و بولس & 25 \\
\hline \multirow[t]{2}{*}{ دير راهبات عامر - 1996 - بقترفيا من من الكنيسة المجع } & بلقاس الدقهلية & القرن 12/ ال 13 & دير القديسة دميانة & 26 \\
\hline & أجا الدقهلية & قبل القرن 7 & دير مار جرجس & 27 \\
\hline دير أثري & 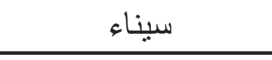 & سنة 545 & دير سانت كاترين & 28 \\
\hline دير رهبان & رأس سدر سيناء & & دير موسى النبي & 29 \\
\hline
\end{tabular}




\begin{tabular}{|c|c|c|c|c|}
\hline ملاحظــــــات & الموقع & تاريخ التأسبيس & أسم الدير & 5 \\
\hline دير رهبان سنة - 1996 - دير أثنري المجمع & البحر الأحمر & القرن 4 / 5 & دير القديس الأنبا بو لا & 30 \\
\hline دير رهبان عامر - معترف به من المجمع 1996 من & البحر الأحمر & القرن 13/9 & دير القديس الأنبا أنطونيوس & 31 \\
\hline أطلال & جبل الجلالة السويس & القرن 4 & دير الأب يوحنا الدرجي & 32 \\
\hline دير اليعاقبة & & & دير العزبة & 33 \\
\hline دير اليعاقبة & & & | دير ابو النعناع & 34 \\
\hline دير اليعاقبة & & & (ير الخندق & 35 \\
\hline دير اليعاقبة & & & دير سرياقوس دير ابو هور & 36 \\
\hline دير اليعاقبة & & & دير أتريب ( دير ماري مريم) & 37 \\
\hline دير اليعاقبة ـ الكنبسة من القرن 18/17 & قرية طموه الجيزة & قبل القرن 10 & دير القديس مرقوريوس أبو سيفين & 38 \\
\hline دير اليعاقبة ـ أطلال وبقايا أثنار & أبو رواش الجيزة & قبل القرن 10 & دير نهيا & 39 \\
\hline دير اليعاقبة ـ أطلال وبقايا أثار & أطفيح جنوب الصف & قبل القرن 12 & الرير الرسل & 40 \\
\hline دير اليعاقبة ـ أطلال وبقايا أثنار & أطفيح حنوب الجيزة & قبل القرن 12 & دير الميمون ـالانبا انطونيوس التحتاني & 41 \\
\hline المتبقى من الدير الكنيسة الاثرية & أطفيح الجيزة & قبل القرن 12 & دير الأباء الرسل & 42 \\
\hline الكنيسة الحالية ترجع للقرن 19/18 & منيل شيحة الجيزة & قبل القرن 12 & دير الخمسة وأمهم (دير قزمان ودميان) & 43 \\
\hline دير اليعاقبة ـ المبنى الوحيد المتبقي هو & الحوامدية الجيزة & قبل القرن 12 & | ديرالأمبر نتادرس & 44 \\
\hline دير اليعاقبة & & & دير مغارة شقلقيل & 45 \\
\hline 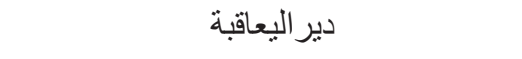 & & & دير بوجرج & 46 \\
\hline دير اليعاقبة & & & دير حماس & 47 \\
\hline دير اليعاقبة & & & دير ابو هرمينه & 48 \\
\hline دير اليعاقبة ـ أطلال وبقايا أثار & 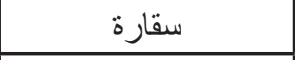 & القرن 6 / 7 & ا دبر الانبا أرميا & 49 \\
\hline \multirow[t]{9}{*}{ أنثري } & سدمنت الجبل الفيوم & القرن 6 & إير مارجرجس & 50 \\
\hline & بجوار اللاهون الفيوم & & إير أبي أسحق & 51 \\
\hline & بجوار اللاهون الفيوم & & | دير سيدة & 52 \\
\hline & العدوة الفيوم & & دير العامل & 53 \\
\hline & المنشأة الفيوم & & ا دير بمويه & 54 \\
\hline & المنشأة الفيوم & & دير فانو & 55 \\
\hline & المنشأة الفيوم & & دير سنورس & 56 \\
\hline & المنشأة الفيوم & & إير أبي شنوده & 57 \\
\hline & المنشأة الفيوم & & دير الصفا & 58 \\
\hline \multirow[t]{2}{*}{ الباقي منه مغارتين } & بحيرة قارون الفيوم & بين القرن 7 - 9 & دير أبو الليف & 59 \\
\hline & جبل النقلون الفيوم & القرن 6 & دير الملاك جبر ائيل (دير أبو حبشة) & 60 \\
\hline \multirow[t]{2}{*}{ دير رهبان } & قريب قيشّا الفيوم & القرن 12 & دير العزب (دموشيه) (دير الأنبا إبرام) & 61 \\
\hline & و ادي الريان الفيوم & & دير الأنبا مكاريوس السكندري & 62 \\
\hline تم تجديده في القرن 19 & |الحمام باللاهون الفيوم & قبل القرن 12 & دير السيدة العذر اء مريم & 63 \\
\hline تم تجديد الكنبسة القرن 18/19 & قرية دسيا الفيوم & القرن 8 & دير الثهيد تاوضروس & 64 \\
\hline تم تجديد الكنيسة القرن 18/19 & عين السيلين الفيوم & قبل القرن 18 & ا دير أبو سيفين & 65 \\
\hline تاريخ استيطان الر اهبان مع انطونيوس & الواسطى بني سويف & 305 & 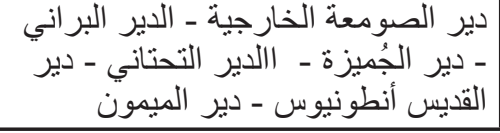 & 66 \\
\hline
\end{tabular}




\begin{tabular}{|c|c|c|c|c|}
\hline ملاحظــــــات & الموقع & تاريخ التأسيس & أسم الدير & 5 \\
\hline \multirow{6}{*}{ دير راهبات ـ الكنيسة الحالية من الستينات } & بياض - بني سويف & القرن 15 & دير العذر اء مريم (دير بياض) & 67 \\
\hline & أهناسيا بني سويف & القرن 7 / 8 & دير الثهيد مار جرجس & 68 \\
\hline & بوش بني سويف & القرن 16 & دير الانبا أنطونيوس & 69 \\
\hline & بوش بني سويف & 19/18 19 القرن & دير الانبا بو لا & 70 \\
\hline & الحمام بني سويف & القرن & دير السيدة العذر اء (الانبا اسحق) & 71 \\
\hline & مصر الوسطى & & دير القديس برسوم & 72 \\
\hline دير رهبان عامر - معترف بنه من المجمع 1996 دقد & جبل القلمون مغاغة & القرن & دير الأنبا صمئويل المعترف & 73 \\
\hline \multirow[t]{3}{*}{ الكنيسة ترجع القرن 19} & 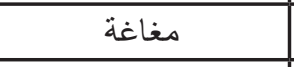 & 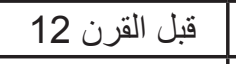 & دير الجرنوس & 74 \\
\hline & سوادة المنيا & 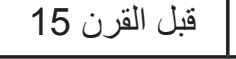 & دير القديس أبا هور & 75 \\
\hline & منهري أبي قرقاص & قبل القرن 15 & دير العجايبي & 76 \\
\hline دير رهبان - الباقي هو الكنيسة فقط & بلدة هور ملوي & القرن & دير أبو فانا (دير الصليب) & 77 \\
\hline دير اليعاقبة ـ الكنبسة ترجع القرن 18 / 19 & |قرية الريرمون ملوي & قبل القرن 18 & دير الملاك & 78 \\
\hline \multirow{4}{*}{ أطلال وبقايا } & 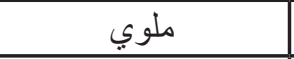 & قبل 1672 & دير الديك & 79 \\
\hline & منطقة أصنا ملوى & قبل 1672 & دير سنباط & 80 \\
\hline & منطقة أنصنا ملوى & & دير النصارى & 81 \\
\hline & البرشا ملوي & & دير أبو فام (الجندي) & 82 \\
\hline دير اليعاقبة & 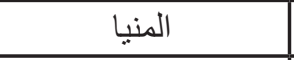 & 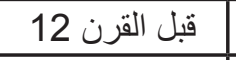 & دير أباهور الر اهب ( دير سو ادة) & 83 \\
\hline أطلال وبقايا كنبسة القرن 19/18 & بني مزار البهنسا & ترجع القرن 6 & دير السنقورية & 84 \\
\hline ترجع الكنيسة القرن 18 / 19 & ديروط & قبل القرن 12 & دير الانبا صر ابامون & 85 \\
\hline \multirow[t]{2}{*}{ دير أنزي } & قرية باويط دبروط & ق قبل القرن 15 & دير أبوللو باويط & 86 \\
\hline & عزبة دوس ديروط & 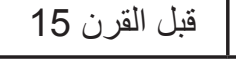 & دير المشرقي & 87 \\
\hline \multirow[t]{3}{*}{ دير اليعاقبة - ترجع الكنبسة القرن 18 / 19} & مدينة بصنبو ديروط & قبل القرن 12 & دير العجايبي (مارمينا) & 88 \\
\hline & كودية النصارى & & دير الانبا إبر ام و الثُهيد تادرس المشرقي & 89 \\
\hline & ديروط & & دير الانبا إبرام والثهيد مار مينا & 90 \\
\hline دير راهبات & ديروط & & ديخائيل السيدة العذراء ورئيس الملائكة & 91 \\
\hline من مسار العائلة المقدسة & جبل الطبر سمالوط & قبل القرن 10 & دير السيدة العذر اء & 92 \\
\hline دير اليعاقبة & عزبة دروس أسيوط & & دير الأمير تقططر ادرس & 93 \\
\hline دير رهبان - ترجع الكنيسة القرن 15 / 17 & جبل قاو البراري & القرن 5/4 & دير القديس هرمينا السائح & 94 \\
\hline من مسار العائلة المقسة & القوصية & & دير القصير للسيدة العذراء & 95 \\
\hline المقدس رهنة 1996 - معترف العائلة المقدسية المجن & القوصية اسيوط & قبل القرن 12 & دير السيدة العذراء (المحرق) & 96 \\
\hline \multirow[t]{5}{*}{ دير رهبان - الدير منحوت في الجبل ـ أثر } & أبنوب أسيوط & القرن & دير مار مينا العجايبي ”الدير المعلق" & 97 \\
\hline & جبل درنكة أسيوط & 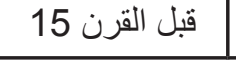 & دير السيدة مريم العذراء & 98 \\
\hline & جبل درنكة أسيوط & قبل 1902 & دير العظام & 99 \\
\hline & جبل درنكة أسيوط & 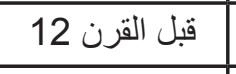 & دير الموتين & 100 \\
\hline & جبل درنكة أسيوط & قبل القرن 15 & 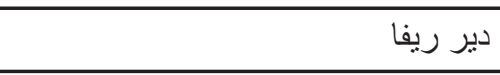 & 101 \\
\hline ترجع الكنيسة القرن 18 / 19 & أبوتيج أسيوط & قبل القرن 12 & دير أبو مقار - دير العذراء (الجنادلة) & 102 \\
\hline دير اليعاقبة & & & دير بالوجه & 103 \\
\hline
\end{tabular}




\begin{tabular}{|c|c|c|c|c|}
\hline ملاحظــــــات & الموقع & تاريخ التأسبس & أسم الدير & 5 \\
\hline دير اليعاقبة & & & دير مرقورة & 104 \\
\hline دير اليعاقبة & & & دير الجاولية & 105 \\
\hline دير اليعاقبة & & & دير المطل & 106 \\
\hline \multirow[t]{2}{*}{ دير اليعاقبة } & منفلوط & & دير غبريال & 107 \\
\hline & بني شقير منفلوط & قبل القرن 15 & دير الأمير تادرس الثطبي & 108 \\
\hline أطلال وبقايا أنثار & شرق منفلوط & قبل القرن 15 & دير مارمينا المعلق & 109 \\
\hline ترجع الكنيسة القرن 18 / 19 & أبنوب & ق ق قبل القرن 18 & دير مار بقطر & 110 \\
\hline \multirow[t]{2}{*}{ ترجع الكنيسة القرن 18 / 19} & عرب العوامر أبنوب & قبل القرن 18 & دير أبو اسحق & 111 \\
\hline & السلاموني اخميم & القرن 15 / 17 & ل دير الملاك ميخائيل & 112 \\
\hline أطلال وبقايا أثار & العبساوسية أخميم & القرن 15 / 17 & دير مارجرجس الحديدي & 113 \\
\hline دير رهبان & حي الكوثر أخميم & 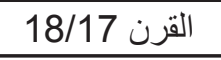 & دير الشهداء & 114 \\
\hline دير اليعاقبة ـ المقريزي - خرب & & قبل القرن 15 & دير اقفاص ( اقفهس ) & 115 \\
\hline \multirow[t]{2}{*}{ دير رهبان - دير اليعاقبة دير باخومية } & قرية الحواوبش أخميم & 17/16 القرن & دير السيدة العذراء مريم (دير العين) & 116 \\
\hline & برية شنشيف اخميم & القرن 16 / 17 & دير الانبا شنودة الثرقي & 117 \\
\hline دير رهبان - دير اليعاقبة باخومية & جرجا أخميم & ق قبل القرن 16 & إير الملاك ميخائيل & 118 \\
\hline دير باخومية & 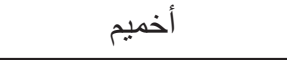 & & دير مينه & 119 \\
\hline 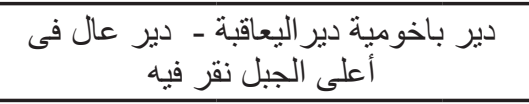 & السلاموني اخميح & قبل القرن 15 & دير القرقس (داخل السبع جبال) & 120 \\
\hline دير باخومية & قرية الأحايوة جرجا & القرن 7 / 8 & إير الانبا بسادة & 121 \\
\hline دير باخومية & أخميم & & دير أبو جليانة & 122 \\
\hline \multirow[t]{2}{*}{ دير اليعاقبة باخومية - يعرف بجبل الكهف } & أخميم & قبل القرن 10 & | دير الطبر & 123 \\
\hline & نجع فرج أخميم & فبل القرن 16 & دير الأنباتوماس & 124 \\
\hline \multirow[t]{2}{*}{ أطلال وبقايا } & الصو امعة أخميم & القرن 6/ 7 & دير الأنبا باخوم وضالومشام اخته & 125 \\
\hline & الصو امعة أخميم & القرن 18 & دير الامير تادرس(تاوضروس) المشرقي & 126 \\
\hline \multirow[t]{2}{*}{ أطلال وبقايا } & سو هاج & القرن 6 & دير الانبا يشاي بالجبل الغربي & 127 \\
\hline & البلينا - الينا & القرن 19/18 & | دير النغاميش & 128 \\
\hline دير راهبات & البلينا & فبل القرن 12 & دير الثُهيدة دمبانة وامويسيس الابيدوسي & 129 \\
\hline دير اليعاقبة باخومية & نجع الدير المنشأة & القرن4 & دير ابو بشادة الأسقق & 130 \\
\hline دير اليعاقبة & الجنادلة أسيوط & فبل القرن 15 & دير العذراء - (الأنبا مقرفيوس) & 131 \\
\hline دير اليعاقبة & الحاجر درنكة أسيوط & فبل القرن 15 & دير أبو بغام & 132 \\
\hline دير اليعاقبة & & & | دير بوشنوده & 133 \\
\hline دير اليعاقبة & العر ابة المدفونة & القرن 6 & دير الثهيدة دميانة والقديس أبو مسبس & 134 \\
\hline دير باخومية & سو هاج & سنة & دير الأنبا شنودة ـ الدير الأبيض & 135 \\
\hline \multirow[t]{2}{*}{ دير باخومية } & سو هاج & القرن الر ابع & دير الأنبا بيجول ـ الدير الاحمر & 136 \\
\hline & جبل قاو مركز البداري & القرن 5/4 & دير هرمينا السائح & 137 \\
\hline \multirow[t]{2}{*}{ دير باخومبة } & العراية المدفونة & القرن 4 & دير الثشيده دميانه و الانبا موسبس & 138 \\
\hline & المر اغة سوهاج & القرن 18 & دير الثهيدان كيريانوس ويوستينا & 139 \\
\hline \multirow[t]{4}{*}{ دير باخومية ـ الباقي الكنبسة } & قرية المحروسة قنا & القرن 19/18 & دير مارجرجس الحديدي & 140 \\
\hline & نقادة قنا & القرن 4 & دير مارجرجس الروماني & 141 \\
\hline & نقادة قنا & القرن 18 & |دير الصليب المقدس & 142 \\
\hline & نقادة قنا & القرن 19/18 & دير أندراس أبو الليف & 143 \\
\hline
\end{tabular}




\begin{tabular}{|c|c|c|c|c|}
\hline ملاحظــــــات & الموقع & |تاريخ التأسيس & أسم الاير & 5 \\
\hline دير اليعاقبة & حاجر نقادة قنا & القرن 4 & دير الفديس الانبا مار بقطر & 144 \\
\hline دير رهبان - أطلال وبقايا & 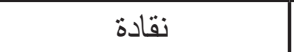 & القرن 19/18 & دير الملاك ميخائيل & 145 \\
\hline \multirow[t]{3}{*}{ أطلال وبقايا } & المحروسة نقادة & القرن 19/18 & دير مارجرجس & 146 \\
\hline & نقادة & القرن 19/18 & دير الانبا بسنتاؤس & 147 \\
\hline & قامو لا نقادة & 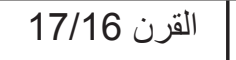 & دير الملاك ميخائيل & 148 \\
\hline \multirow[t]{2}{*}{ راهبات } & نجع حمادي & قبل القرن 15 & دير مارمينا العجايبي & 149 \\
\hline & فرية حجارة قوص & القرن 19/18 & دير مار بقطر & 150 \\
\hline \multirow{2}{*}{ راهبات - دير باخومية - دير أثري } & زليتين نجع حمادي & القرن 17/16 & دير الانبا بضايا & 151 \\
\hline & |بهجورة نجع حمادي & 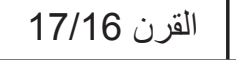 & دير الانبا بضايا & 152 \\
\hline الكنيسة الأثرية الوحيدة الباقية الدير القديم & قرية القصر و الصباد & القرن 4 & دير الانبا بلامون & 153 \\
\hline دير اليعاقبة & درنكة أسيوط & قبل القرن 15 & دير بوجرج & 154 \\
\hline دير اليعاقبة & درنكة أسيوط & قبل القرن 15 & دير بوساويرس & 155 \\
\hline دير البعاقبة & درنكة أسيوط & قبل القرن 15 & دير منسي آلى & 156 \\
\hline \multirow[t]{2}{*}{ دير البعاقبة } & درنكة أسيوط & قبل القرن 15 & دير موشه & 157 \\
\hline & ساقلته اخميم & القرن & دير الأنبا توماس السائح & 158 \\
\hline دير رهبان عامر - معترف بنه من المجمع 1996 دقد & الزريقات ارمنت & القرن 19 & دير القديس مار جرجس & 159 \\
\hline \multirow[t]{2}{*}{ دير رهبان - دير باخومية } & الأقصر & القرن 18/17 & دير الأنبا باخوميوس ”الثشايب“" & 160 \\
\hline & الاقصر & القرن 15 & دير تاوضروس المشرقى ـ المحارب & 161 \\
\hline أطلال وبقايا & الاقصر & & دير فيبامون (أبو فام) & 162 \\
\hline أطلال وبقايا & الاقصر & & ديرمار أبيفانيوس & 163 \\
\hline \multirow[t]{3}{*}{ أطلال وبقايا } & الاقصر & & دير كيرياكوس & 164 \\
\hline & طود أرمنت & 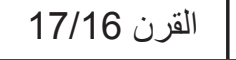 & دير الانبا بشاي والانبا بطرس & 165 \\
\hline & أرمنت & & دير الساقية & 166 \\
\hline \multirow[t]{2}{*}{ أطلال } & أرمنت & & دير المسيكرة (دير الناموس) & 167 \\
\hline & 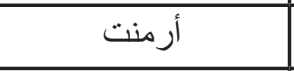 & & دير النصارى & 168 \\
\hline بقايا & أرمنت & & دير البعيد & 169 \\
\hline أطلال و بقايا & 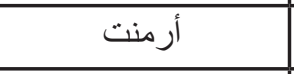 & & الدير المدفون (الدير الأبيض) & 170 \\
\hline دير رهبان & 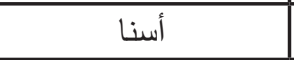 & قبل القرن 12 & دير الانبا متاؤس الفاخوري & 171 \\
\hline أطلال و بقايا & أسنا & & دير الرومانية & 172 \\
\hline مكان دير قديم يسمى دير انبا اسحق الكنيسة 19 19 القرن & أسنا & قبل القرن 17 & دير الشهدداء & 173 \\
\hline 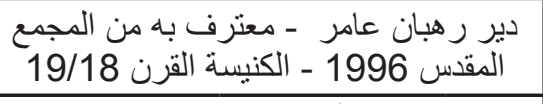 & إدفو & القرن 4 - & دير الانبا باخوميوس & 174 \\
\hline أطلال و بقايا & أسوان & قبل القرن 12 & دير مار جرجس (قبة الهواء) & 175 \\
\hline دير باخومية ـ أطلال و بقايا آثار & 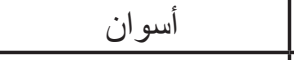 & القرن 5 & دير الأنبا سمعان & 176 \\
\hline أطلال على بقايا حصن روماني & | الخارجة الو ادي الجديد & القرن & دير مصطفى كاثنف & 177 \\
\hline \multirow[t]{3}{*}{ عين سعف كانت مساكن للبجوات } & | الخارجة الو ادي الجديد & 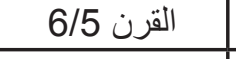 & عين سعف & 178 \\
\hline & |الداخلة الوادي الجديد & & دير أبو متى & 179 \\
\hline & | الداخلة الوادي الجديد & & دير الملوك & 180 \\
\hline
\end{tabular}


هالاديرة الاثرية في مصر ، ك ك والترز ، ترجمة : إبراهيم سلامة إبراهيم ، 2002 ، المجلس القومي

• الأديرة المصرية العامرة ـ الأنبا صموئيل تاوضروس السرياني ، المطبعة التجارية بالقاهرة ، 1968

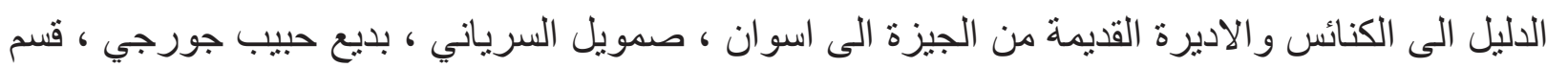
العمارة القبطية بمعهد الدراسات القبطية ، القيرة الفيزة

• الديارات ، الثابشتي ، تحقيق كوركيس عو اد ،2 ، مطبعة المعارف بغداد ، 1966 • الديار ات في معجم البلدان لياقوت الحموي ، تحقيق يوحنا الحبيب صادر ، دار صادر بيروت

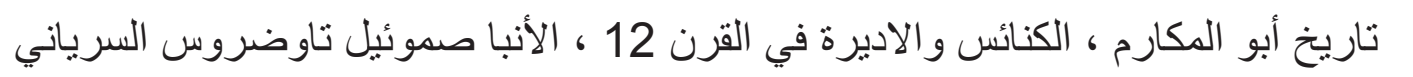

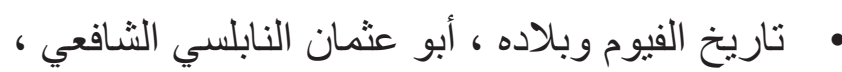

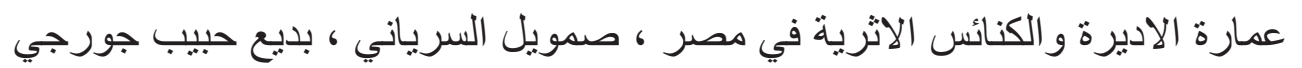
• دليل المتحف القبطي واهم الكنائس والأديرة الاثرية ، مرقس سميكة باشا ، المطابع الاميرية ، 1930

- Abu Salih, The Armenian, Churches and Monasteries of Egypt AND Some Neighbouring Countries , AT The Clarendon Press , 1895

- William Harmless. Desert Christians: An Introduction to the Literature of Early Monasticism, Oxford University Press, Jun 17, 2004.

- Gawdat Gabra , Coptic Monasteries , Egypt's Monastic Art and Architecture , AUC Press , 2002

- Claremont Colleges Digital Library

https://ccdl.claremont.edu/digital/collection/cce/search/searchterm/ monasteries/field/subjec/mode/exact/conn/and/page/17

- Monastères et sites monastiques d'Égypte https://www.ifao.egnet.net/bases/publications/bec23/about

- Yale in Egypt

Kellia and Pherme

https://egyptology.yale.edu/expeditions/current-expeditions/yale-monasticarchaeology-project-north-ymap-north/kellia-and-pherme 
